\title{
Climate of the last millennium at the southern pole of the North Atlantic Oscillation: an inner-shelf sediment record of flooding and upwelling
}

\author{
F. Abrantes ${ }^{1,2, *}$, T. Rodrigues ${ }^{1,2}$, B. Montanari ${ }^{1}$, C. Santos ${ }^{1,2}$, L. Witt ${ }^{3}$, C. Lopes ${ }^{1,2}$, \\ A. H. L. Voelker ${ }^{1,2}$ \\ ${ }^{1}$ Laboratório Nacional de Energia e Geologia (LNEG), Unidade de Geologia Marinha, Apartado 7586, \\ 2721-866 Amadora, Portugal \\ ${ }^{2}$ Centro de Investigação Marinha e Ambiental (CIMAR), 4050-123 Porto, Portugal \\ ${ }^{3}$ Pacific Fisheries Environmental Laboratory, Pacific Grove, California 93950-2097, USA
}

\begin{abstract}
Continental and marine conditions during the last millennium off Porto, Portugal (the southern pole of the North Atlantic Oscillation, NAO), are reconstructed from a sediment archive through a high-resolution multiproxy study and instrumental evidence. Results show multidecadal variability and sea surface temperatures (SSTs) that correlate well with previously published landand sea-based Northern Hemisphere temperature records, and appear to be responding to long-term solar insolation variability. Precipitation was negatively correlated with the NAO, whereas strong flooding events occured at times of marked climate cooling (AD 1100-1150 and 1400-1470) and transitions in solar activity. AD 1850 marks a major shift in the phytoplankton community associated with a decoupling of $\delta^{18} \mathrm{O}$ records of 3 planktonic foraminifera species. These changes are interpreted as a response to a reduction in the summer and/or annual upwelling and more frequent fall-winter upwelling-like events. This shift's coincidence with a decrease in SST and the increase in coherence between our data and the Atlantic Multidecadal Oscillation (AMO) confirms the connection of the upwelling variability to the North Atlantic Ocean's surface and thermohaline circulation on a decadal scale. The disappearance of this agreement between the AMO and our records beyond AD 1850 and its coincidence with the beginning of the recent rise in atmospheric $\mathrm{CO}_{2}$ supports the hypothesis of a strong anthropogenic effect on the last $\sim 150 \mathrm{yr}$ of the climate record. Furthermore, it raises an important question of the use of instrumental records as the sole calibration data set for climate reconstructions, as these may not provide the best analogue for climate beyond AD 1730.
\end{abstract}

KEY WORDS: Climate - Last millennium - NAO - Sediment record · Precipitation · Flooding · Upwelling $\cdot$ Portugal $\cdot$ AMO $\cdot$ Gulf Stream

\section{INTRODUCTION}

The forecast quality of climatic trends depends on the ability to distinguish between anthropogenic climate change and natural climate variability. Given the relatively short period of the instrumental data set, a better understanding of the climate dynamics will only be possible through widespread, accurate and quantitative records of past climate, in particular, multiparameter high-resolution histories of climate change and environmental response during the last millennium in key ocean areas.

The North Atlantic Ocean is such an area. Here, climate is greatly determined by the North Atlantic Oscillation (NAO). Variations in the NAO index (the December to March difference in atmospheric pressure at sea level [SLP] between the Iceland Low and the Azores High) occur on time scales from daily to multidecadal. In the Iberian Peninsula, strong westerlies and storms occur in winters with a negative NAO 
index, whereas upwelling-favourable winds characterize positive NAO index winters (Hurrell 1995). Besides these known winter effects (Trigo et al. 2002), new research shows that the NAO also influences the summer climate in this area (Folland et al. 2009).

NAO variability is also related to changes in the North Atlantic sea surface temperature (SST) and large-scale ocean circulation (Curry \& Mauritzen 2005, Marshall et al. 2001) through the Atlantic Multidecadal Oscillation (AMO) (Kerr 2000). The AMO varies on multidecadal time scales $(60-80 \mathrm{yr}$ period; Schlesinger \& Ramankutty 1994) and is closely but inversely related to the NAO with a lag of several years (e.g. Rogers 1985, Grossmann \& Klotzbach 2009). AMO positive phases are characterized by widespread warm SST anomalies and maximum Atlantic Meridional Overturning Circulation (AMOC) (Delworth \& Mann 2000, Knight et al. 2005). During AMO negative phases, SST is anomalously cool and AMOC reaches its minimum. These general cooling (warming) conditions decrease the temperature and pressure gradients of the North Atlantic and result in a negative feedback that switches the NAO towards positive (negative) phases (Grossmann \& Klotzbach 2009). The AMOC acts not only as a radiator for Western Europe as it also transfers the atmospheric changes into the deep ocean and the thermohaline circulation (THC) via the formation of deep waters in the higher latitudes of the North Atlantic (Dickson \& Brown 1994, Grossmann \& Klotzbach 2009).

Deep-water production has been shown to vary on sub-annual to millennial time scales through both the analyses of instrumental data (Nuñez-Riboni et al. 2010) and the study of sediment records (e.g. Bianchi \& McCave 1999, Thornalley et al. 2009). More recently, Hall et al. (2010) and Miettinen et al. (2010) have shown that, at least over the last $230 \mathrm{yr}$, changes in deep flow speed are coordinated with the surface South Polar North Atlantic salinity on multidecadal time scales.

Given the strong salinity-density relationship at water temperatures near freezing, the freshening of the north Atlantic is believed to be one of the main forces behind the decrease in AMOC and deep-water formation. Important clues on that relationship have been provided by ice sheet and north Atlantic sediments data and past climate models that indicate that the freshening of the north Atlantic halts the production of North Atlantic deep water. This halt greatly reduces the input of warm water into the North Atlantic and produces a very cold Northern Hemisphere climate (Ganopolski \& Rahmstorf 2001). Strong climatic shifts with this origin prevailed during the last glacial period (marine isotope stages 4-2) and occurred in short periods (decades). A weakened ver- sion (smaller temperature gradient) of this variability has also occurred throughout the present interglacial period, the Holocene (Mayewski et al. 2004). First explained as a result of changes in the intensity of solar activity (Bond et al. 2001), more recent literature suggests reorganization in the heat transfer by the ocean (e.g. Debret et al. 2009). The Little Ice Age (LIA; AD 1350-1900) that followed a time of warmer climatic conditions known as the Medieval Warm Period (MWP; AD 550-1350) is believed to be the last of these oscillations. Off the Portuguese margin, previous highresolution multi-proxy analysis on the Tagus river system revealed the MWP as a dry productive period and the LIA as a period of important precipitation (Abrantes et al. 2005b, Lebreiro et al. 2006). Furthermore, the MWP was inferred as a time of persistent positive NAO-like state and the LIA as a period of negative NAO-like state.

Climatic and environmental information of much higher resolution for the last $1000 \mathrm{yr}$ and for the time interval missing in the Tagus sequence (AD 1400-1839; Abrantes et al. 2005b) is now provided by a sediment sequence recovered off the second most important Portuguese river system, the Douro. Although this is a single and very localized record, its location in the European region with the highest correlation to NAO turns it into a site of key importance for hemispheric climate reconstructions.

With a mean annual flux one order of magnitude higher than the Tagus (http://snirh.pt), the Douro runoff generates a well-defined low salinity plume over the shelf off Porto where the terrigenous materials transported to the coast tend to become deposited (Dias et al. 2002, Lantzsch et al. 2009; Fig. 1a,b). The circulation in this area is highly seasonal. In winter, as river water is colder than seawater, thermal inversions sustained by haline stratification are commonly observed over the shelf. Over the slope, the warm, highly saline Iberian Poleward Counter Current (IPC) presents its strongest surface signal and northernmost extent (Fig. 1c; Relvas et al. 2007). In the Douro area, the low salinity river plume and the prevailing westerly-southerly winds cause a downwelling regime over the shelf and a rather homogeneous water column, with a deepening of the thermocline to $80-100 \mathrm{~m}$. Furthermore, observations by Oliveira et al. (2007) showed a strong cross-shelf salinity gradient at the surface and the inshore penetration of warm oceanic waters. Winter episodic northerly winds generate upwelling events, offshore expansion of the lowsalinity plume and large onshore transport in the bottom Ekman layer that results in a rapid thermal restratification at mid-shelf (Vitorino et al. 2002, Oliveira et al. 2007). In spring, low salinity waters still cover a significant part of the continental shelf; however, due 

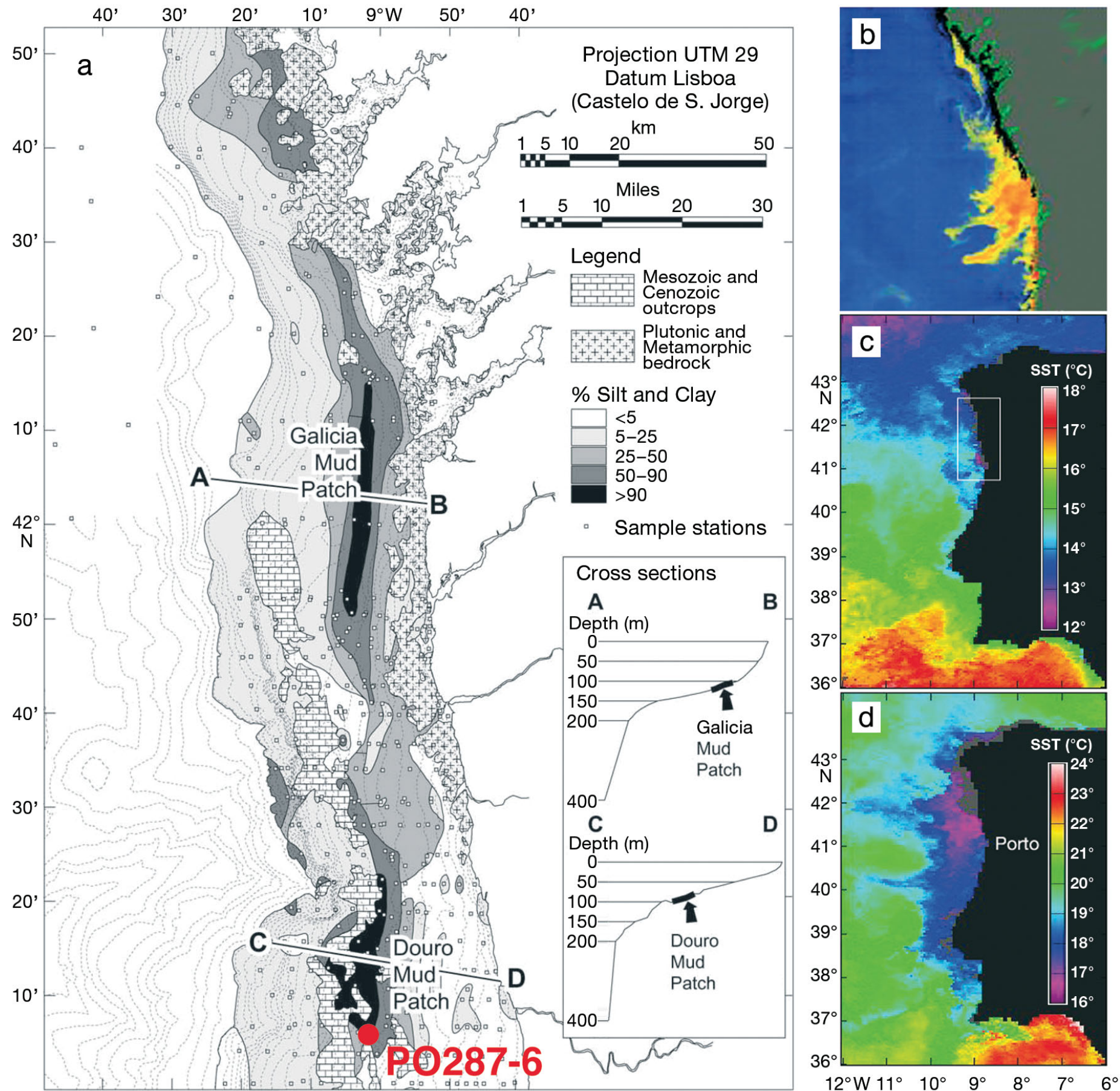

Fig. 1. (a) Site location (red dot), positioned over the distribution of surface sediment facies and outcropping basement rocks on the northwestern Portugal-Galician shelf (modified from Dias et al. 2002 with permission from Elsevier). (b) SeaWIFS satellite image (reflectance at 555 nanometer) of the suspended matter (yellow) representative of the winter Douro River plume (OceanRS_MERIS_Envisat_ESA). (c) Monthly composite of winter (January 2003) sea surface temperature (SST). Land appears black and cloud-covered areas are gray. The white square indicates the area shown in panels a and b. (d) Composite of summer SST (August 1998) showing upwelling conditions (colder SST) along the western Iberian coast. Panels c and d are based on nighttime AVHRR Pathfinder 5 satellite data with $4 \mathrm{~km}$ resolution. The AVHRR Oceans Pathfinder SST data were obtained through the online PO.DAAC Ocean ESIP Tool (POET) at the Physical Oceanography Distributed Active Archive Center (PO.DAAC), NASA Jet Propulsion Laboratory, Pasadena, CA (http://podaac.jpl.nasa.gov/poet) 
to the prevalence of northerly winds from spring to early fall, equatorward currents prevail (Portuguese Current [PC]) and near the shore, upwelling of subsurface cooler and nutrient-rich waters becomes the most significant hydrodynamic process (Fig. 1d; Relvas et al. 2007). As the atmospheric forcing changes, upwelling ceases and fall is marked by the surface expression of the warm water mass that flows as the IPC.

River and upwelling input of nutrients sustain high primary production throughout the year in the Douro region, as reflected by chlorophyll $a(\mathrm{chl} a)$ values of $3.0 \mathrm{mg} \mathrm{m}^{-3}$ and 220 cells ml $\mathrm{m}^{-1}$ that mostly accumulate at the edge of the river plume in winter. In summer, phytoplankton biomass develops mainly below the thermocline, attaining $5.0 \mathrm{mg} \mathrm{m}^{-3} \mathrm{chl} a$ and 120 cells $\mathrm{ml}^{-1}$ (Abrantes \& Moita 1999, Moita 2001, Oliveira et al. 2007, Cabeçadas et al. 2008). These data reflect the dominance of diatoms (with greater biovolumes and higher chl a content) in summer, whereas in winter smaller coccolithophores are the dominant phytoplankters (Moita 2001).

Our site (Fig. 1a) is thus subject to seasonal changes in the dominant oceanographic and sedimentary regime. It receives input of continental sediments via river discharge mostly in winter and early spring, and input of marine microorganisms, mainly during the coastal upwelling season (May-September) and winter northerly wind events.

In the present study, long-term changes in these 2 processes and their forcing factors were investigated through a combination of instrumental and highresolution proxy data. Further comparison to hemispheric climate records was used to identify local responses to hemispheric climate variations.

\section{MATERIALS AND METHODS}

\subsection{Proxy data}

PO287 sediment cores were retrieved in May 2002, during the PALEO1 campaign aboard the German RV 'Poseidon'. Box core PO287-6B $(25 \mathrm{~cm})$ and gravity core PO287-6G $(567 \mathrm{~cm})$ were recovered from $41.4^{\circ} \mathrm{N}$, $8.9^{\circ} \mathrm{W}$ and $80 \mathrm{~m}$ water depth (Fig. 1a).

Magnetic susceptibility (MS) was measured with a multi-parameter logging system and iron (Fe), titanium (Ti) and calcium (Ca) contents (counts per second [cps]) were determined every $2 \mathrm{~cm}$ with X-ray fluorescence (XRF) core scanning for non-destructive semiquantitative analysis of major elements. Both measurements were performed at Marum, Bremen University.

Measurements of grain size, total organic carbon (TOC), biomarker concentrations and diatom and foraminifera analysis were performed every $1 \mathrm{~cm}$ in the box core and every $5 \mathrm{~cm}$ in the gravity core. Grain size analysis was performed with a laser Coulter LS230 after removal of organic matter with hydrogen peroxide $\left(\mathrm{H}_{2} \mathrm{O}_{2}\right)$ and dispersal with sodium hexametaphosphate. TOC content was calculated as weight percent (wt\%) from the difference between total carbon and inorganic carbon concentrations measured on a CHNS-932 LECO elemental analyzer, with an analytical precision of $0.03 \mathrm{wt} \%$.

Oxygen-isotopic compositions were determined on 3 planktonic foraminifera species-Globigerina bulloides, Globigerina inflata, and Neogloboquadrina pachyderma var. dextral and N. pachyderma var. sinistraland the benthic genus Uvigerina sp. on a Finnigan MAT 251 mass spectrometer at Marum, Bremen University. The ${ }^{18} \mathrm{O} /{ }^{16} \mathrm{O}$ ratio is reported in per mil (\%) relative to the Vienna Peedee Belemnite (VPDB) standard. Analytical standard deviation is $\pm 0.07 \%$ for $\delta^{18} \mathrm{O}$ and $\pm 0.05 \%$ for $\delta^{13} \mathrm{C}$.

The long-chain alkenones were determined on $2 \mathrm{~g}$ of homogenized sediment using a Varian 3800 gas chromatograph equipped with a septum programmable injector, following the methods described in Villanueva \& Grimalt (1997) and Villanueva et al. (1997). Analytical precision is $0.5^{\circ} \mathrm{C}$. SST was estimated using in the global calibration based in core-top sediment records (Müller et al. 1998)

Diatom quantification and assemblage determinations followed the methods of Abrantes et al. (2005a).

\subsection{Instrumental data}

Precipitation and SST data correspond to monthly means for a $5^{\circ}$ grid between $\mathrm{AD} 1870$ and 1999 provided by the Climatic Research Unit (CRU; www. cru.uea.ac.uk/cru/data/). River flow data cover $53 \mathrm{yr}$ (AD 1956-2004) at the Pocinho station $\left(41.08^{\circ} \mathrm{N}\right.$, $7.13^{\circ} \mathrm{W}$ ) and are from the Portuguese National Service for Hydrological Resources (SNIRH; http://snirh. inag.pt).

Upwelling intensity is given by upwelling indices (volume of water upwelled as $\mathrm{m}^{3} \mathrm{~s}^{-1} 100 \mathrm{~m}^{-1}$ of coastline) computed at the National Oceanic and Atmospheric Administration Pacific Fisheries Environmental Laboratory (NOAA PFEL) for each meteorological season and the whole year (annual). The index was calculated for a $1^{\circ}$ grid spacing since AD 1969 and a $3^{\circ}$ grid spacing since AD 1947 following Bakun (1973). Calculations with $5^{\circ}$ grid spacing and for the older period (AD 1898-2001) are based on data provided by Minobe et al. (2002). The $1^{\circ}$ index was calculated for $41^{\circ} \mathrm{N}$ and $15^{\circ} \mathrm{W}$, because it corresponds to the $5^{\circ}$ box closest to the coast that does not go over land. 


\subsection{Chronology}

The age model for the spliced sequence composed by the box core PO287-6B and gravity core PO287-6G was constructed via: (1) ${ }^{210} \mathrm{~Pb}$ activity measured in boxcore samples, which, depending on the accepted model, provides a sedimentation rate between 0.32 and $0.43 \mathrm{~cm} \mathrm{yr}^{-1}$ (Fig. 2a); and (2) 4 accelerator mass spectrometry (AMS) radiocarbon measurements (Leibniz-Laboratory for Radiometric Dating and Stable Isotope Research, Kiel, Germany; Table 1). Two further ages were assigned through MS correlation to welldated cores recovered off Lisbon (Fig. 2b). Raw AMS ${ }^{14} \mathrm{C}$ dates were reservoir corrected by $400 \mathrm{yr}$ (Abrantes et al. 2005b) and converted to calendar ages with the INTCAL04 data set (Reimer et al. 2004). The obtained calendar ages are presented in years AD.

The splicing of the gravity with the box core (PO287$6 \mathrm{~B}, \mathrm{PO} 287-6 \mathrm{G})$ was done through the Fe content of both cores. Further integration was based on the AD
1952 age found at $20.7 \mathrm{~cm}$ (depth corrected for compaction during sub-sampling) in box core PO287-6B; an age that is within the error of the age estimated for the same depth using the sedimentation rate that results from a linear interpolation of the 5 dated levels following Jan Heinemeier (Aarhus University, Denmark, pers. comm.) and Narayan et al. (2010) (Table 1, Fig. 2c).

The sedimentation rate found for the spliced sequence is $0.54 \mathrm{~cm} \mathrm{yr}^{-1}$, i.e. each sediment sample represents $2 \mathrm{yr}$.

\subsection{Statistical analysis}

Correlations were performed using the raw values of $\mathrm{AD}$ dates with both instrumental and proxy data. The strength of the relationship between each data set's pair is available as supplementary material (Tables S1 \& S2 in the supplement at www.int-res.com/articles/ suppl/c048p261_supp.pdf.
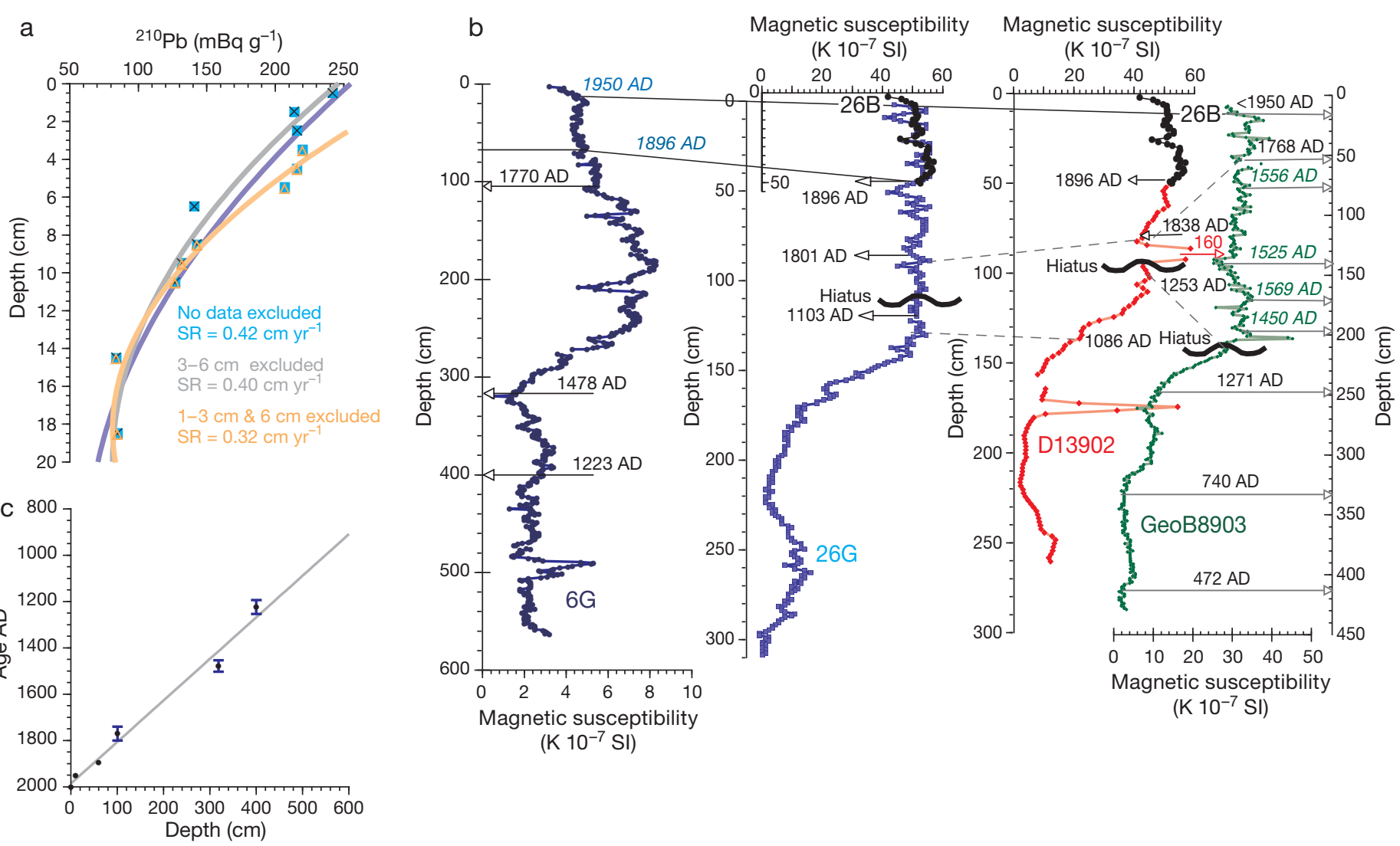

Fig. 2. Information used to construct our age model. (a) ${ }^{210} \mathrm{~Pb}$ activity downcore PO287-6B (box core). SR: sedimentation rate. (b) Magnetic susceptibility record correlation of PO287-6G (gravity core) to sedimentary sequences from the Tagus system (modified from Abrantes et al. 2008 with permission from Elsevier). Black arrows and associated numbers designate calibrated accelerator mass spectrometry ${ }^{14} \mathrm{C}$ ages obtained for the respective core and a wavy line a hiatus. The red arrow and number 160 in core D13902 indicate that the magnetic susceptibility values at this level reach a maximum value of 160 (see Abrantes et al. 2005b for explanation). Black lines correlating features in the PO287-6G sequence with either 26G or GeoB8903 show ages (given in blue italic) that were transferred from these latter records into the PO287-6G age model. Dashed lines connect points of similar age in the different cores. (c) Depth vs. AD ages (with $2 \sigma$ error) for PO287-6G with a linear best fit 
Table 1. Results of ${ }^{14} \mathrm{C}$ accelerator mass spectrometry dating (means $\pm \mathrm{SE}$ ) of the gravity core PO287-6G. Ages were reservoir corrected by $400 \mathrm{yr}$ (years before present, yr BP) as well as converted into calendar years (AD)

\begin{tabular}{|c|c|c|c|c|}
\hline Sample ID & $\begin{array}{l}\text { Depth } \\
\text { (cm) }\end{array}$ & $\begin{array}{c}{ }^{14} \mathrm{C} \text { age } \\
\text { (yr BP) }\end{array}$ & Age AD & Description \\
\hline KIA 35149 & 100.5 & $160 \pm 25$ & 1770 & Mixed 1 \\
\hline KIA 29290 & 318.0 & $405 \pm 35$ & 1478 & Mixed planktonics \\
\hline KIA 35150 & 400.0 & $820 \pm 30$ & 1223 & Mixed benthics \\
\hline
\end{tabular}

Spectral analysis was performed with the REDFIT software, given that our sediment sequence is not equally sampled (Schulz \& Mudelsee 2002).

\section{SCIENTIFIC APPROACH}

Determining the variability in the ocean-climate system over decadal time scales is challenging because the ${ }^{210} \mathrm{~Pb}$ data reveal bioturbation in the topmost samples of the box-core (Fig. 2a) and AMS ${ }^{14} \mathrm{C}$ dating has an average error of $\pm 25 \mathrm{yr}$, that is, too imprecise to resolve the exact timing of events. However, Trauth et al.'s (1997) investigation suggests that, although bioturbation is likely to have existed throughout the sedimentation of the sequence under analysis, the original signal is likely to be preserved. Furthermore, the regional quality of the well-accepted proxies proposed is evaluated at the regional scale by investigating the existing relationship between them and the existing instrumental data for the local operating processes. That is, we accept the uncertainties of both data sets (proxy and instrumental) and consider the highest significant correlation coefficients (Table S1) as an indication of the existence of a strong relationship. The information gained from those correlations is used to reconstruct variations during the preceding millennium.

\section{MODERN CONDITIONS AND PROXY CORRELATIONS}

Most proxies, in particular those related to microorganisms, reflect a combined effect of the 2 main operating processes in this area, river flow and coastal upwelling (Table S1).

SST determinations, based on the alkenone index $\mathrm{U}^{\mathrm{K}^{\prime}}{ }_{37}$, indicate annual upwelling intensity as the determinant factor for SST variability (Table S1), confirming the Tagus results (Abrantes et al. 2009) and the importance of upwelling in controlling the blooms of the alkenone-synthesizing organisms.
River water input is investigated through a set of proxies such as MS, sediment particle size and Fe and Ti content (Abrantes et al. 2005b, Ortiz \& Rack 1999). Both elements are widely used as indicators of fluvial terrigenous input to marine sediments (e.g. Peterson et al. 2000) and show significant inverse correlations to the Douro flux and positive relation to the upwelling index (Table S1). Although these elements are transported from the continent in the river suspended load, these results claim the importance of the 2 processes' interplay mainly during the summer/upwelling season.

Other proxies for continental input are the sediment content in $<63 \mu \mathrm{m}$ particles (\% fine fraction; FF), the alkane [n-alk] and alcohol [n-OH] contents (both biomarkers for terrestrial plants), freshwater diatoms, and phytoliths (grass cell's microscopic isotropic silica precipitates). All proxies show positive correlations to the Douro flux (Table S1) confirming their validity for river input reconstruction.

Primary production used proxies such as TOC, total alkenones, and diatom abundance and composition (Abrantes 1988, Villanueva et al. 1997, Fischer \& Wefer 1999). Marine diatoms and TOC variability through time emerge as determined by the fall extension of the upwelling season. The resting spores generated by some genera, such as Chaetoceros (a survival strategy when water column nutrient content decreases), show relationships to upwelling intensity during the summer/upwelling season, but respond also to winter upwelling (Table S1).

The water column structure is evaluated from multispecies planktonic foraminifera oxygen isotopes and nutrient levels from the planktonic $\delta^{13} \mathrm{C}$ data (Fischer \& Wefer 1999). The isotopic data reveal that Globigerina bulloides $\delta^{18} \mathrm{O}$ is linked to upwelling intensity in the summer/upwelling season, Neogloboquadrina pachyderma var. dextral $\delta^{18} \mathrm{O}$ is related to fall upwelling and Uvigerina $\delta^{18} \mathrm{O}$ is negatively correlated to the winter upwelling index. G. bulloides and Uvigerina $\delta^{13} \mathrm{C}$ correlate with the winter upwelling and river flux, respectively (Table S1), reflecting the determinant effect of the occurrence of high primary production in winter.

\section{DOWNCORE RESULTS AND DISCUSSION}

\subsection{Sea surface temperature}

Understanding past SST changes at the regional scale is crucial in resolving future climate scenarios and their effects. A visual comparison of alkenoneestimated SST and the instrumental data reveals that SST values are in accordance with the present-day spring and fall conditions in the study area (Fig. 3) while the correlation exercise (Table S1) points to 


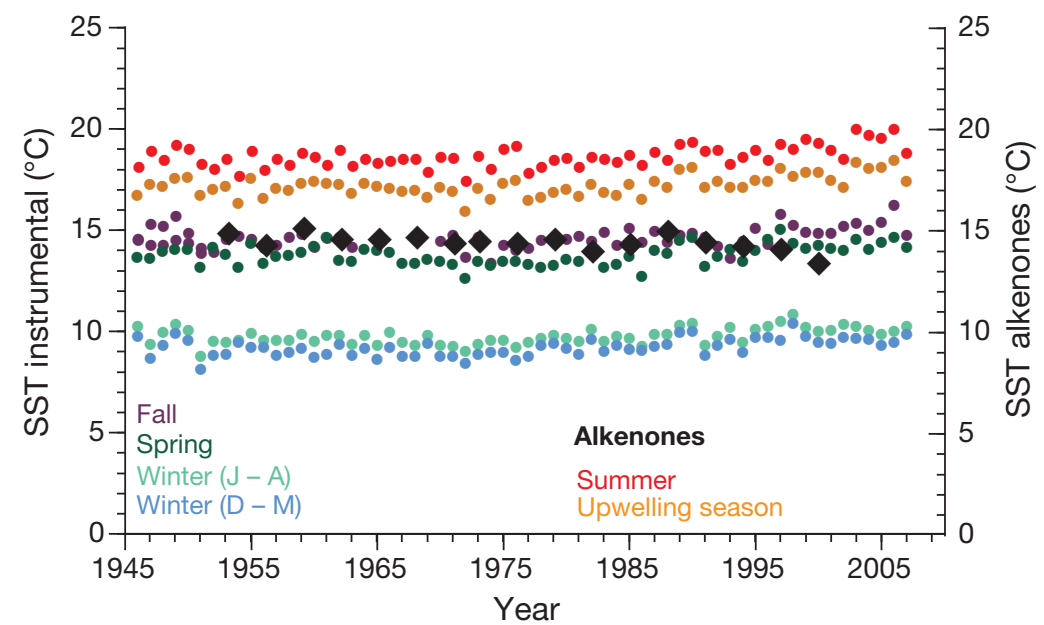

Fig. 3. Alkenone-derived sea surface temperature (SST) measured in box core PO287-6B and instrumentally measured SST at all 4 seasons between AD 1945 and 2007

upwelling intensity as determining decadal SST variation in this coastal upwelling region.

Alkenones are synthesized by isochrysoid haptophytes, some of which also produce coccoliths. As a group, coccolithophores are known to thrive in nutrient-rich but stratified waters (Margalef 1978). The study site is located in an area where new nutrients are brought into the system both by upwelling and by river discharge and the correlations (Table S1) show the interplay of these 2 processes in the record of most of the used proxies. Regional studies by Moita (2001), Oliveira et al. (2007) and Cabeçadas et al. (2008) confirm high river input of nutrients in winter, resulting in blooms of the smaller phytoplankters such as coccolithophores at the river plume boundaries. In summer, during upwelling events, these organisms are pushed offshore by diatom blooms (Moita 2001). However, the interplay between these 2 processes affects the biological response in ways that are still poorly understood, but the model of Gan et al. (2010, p 16-17) revealed that: '(1) the motion of the plume is largely controlled by upwelling circulation over the shelf after the plume exits the river estuary; (2) the algal bloom shows increased efficiency in the surface Ekman layer within the plume layer expanding seaward as it propagates with the dominant current; [and] (3) biological productivity is higher in the plume than that in the upwelled water'. Although the Gan et al. (2010) model is for the South China Sea, their findings are likely to hold elsewhere and help explain that the alkenone-derived SST is determined by the higher production of alkenone producing organisms expected to happen during the period(s) in which river plume and upwelling co-occur.

Downcore, the SST record for the AD 900-2000 period is shown in Fig. 4 a as the estimated value \pm the method's uncertainty versus age $\mathrm{AD} \pm$ the $\mathrm{AMS}{ }^{14} \mathrm{C}$ age uncertainties. The results reveal multi-decadal to multi-centennial variability, with a LIA marked by mean SSTs persistently lower than the also persistently higher temperatures registered in the AD 960-1300 interval that we identify as the MWP. The highest SSTs of this record mark the early MWP, whereas the coldest conditions occur during a major part of the 15th century, with cold periods also in the 17th century (AD 16001680) and the late 19th and 20th centuries (Fig. 4a). The early and cold phase that marks the LIA is followed by a longterm cooling that is interrupted by relatively short and slightly warmer periods, as observed in the middle of the 18th century, e.g. in other western Iberian sites, such as the Tagus (Abrantes et al. 2005b, Lebreiro et al. 2006) and the Galician Rías (Diz et al. 2003).

To assess the temperature history at the Porto shelf on a broader scale, we compared our SST data with other temperature reconstructions available from Europe and the Northern Hemisphere for the last 1-2 millennia (Fig. 4). Visual comparison reveals a good correspondence for the warmer 10th century and centennial variability with the land-based Northern Hemisphere extra-tropical temperature reconstruction of Cook et al. (2004). A more objective comparison was made through the computation of correlation coefficients for the time intervals common to our SST and large-scale North Hemisphere air temperature reconstructions (Table S2). We used the following reconstructions: tree-ring based (Esper et al. 2002), multiproxy based (AD 1500-1980; Huang 2004), compilation of low resolution with tree-ring data (AD 1-1979; Moberg et al. 2005), European seasonal temperature (Luterbacher et al. 2004) and extra tropical tree-ring based (AD 1750-2000; Wilson et al. 2007) the following reconstructions. The highest significant correlation was found for Moberg et al.'s (2005) reconstruction (Fig. 4b), but the correlation to the summer and fall European temperatures of Luterbacher et al. (2004) was also significant (Fig. 4c). Because Moberg et al.'s (2005) reconstruction is the one that extends the furthest back in time, this result is an indication that SST best follows the Northern Hemisphere atmospheric temperature in the older sections of the compared records. Furthermore, the correlation to the European summer temperatures appears to confirm the summer coastal upwelling (a response to alongshore winds, generally stronger at NAO+ conditions) as the determinant factor for SST variability at the regional level. An indication confirmed by the positive correlation with 
AGE AD
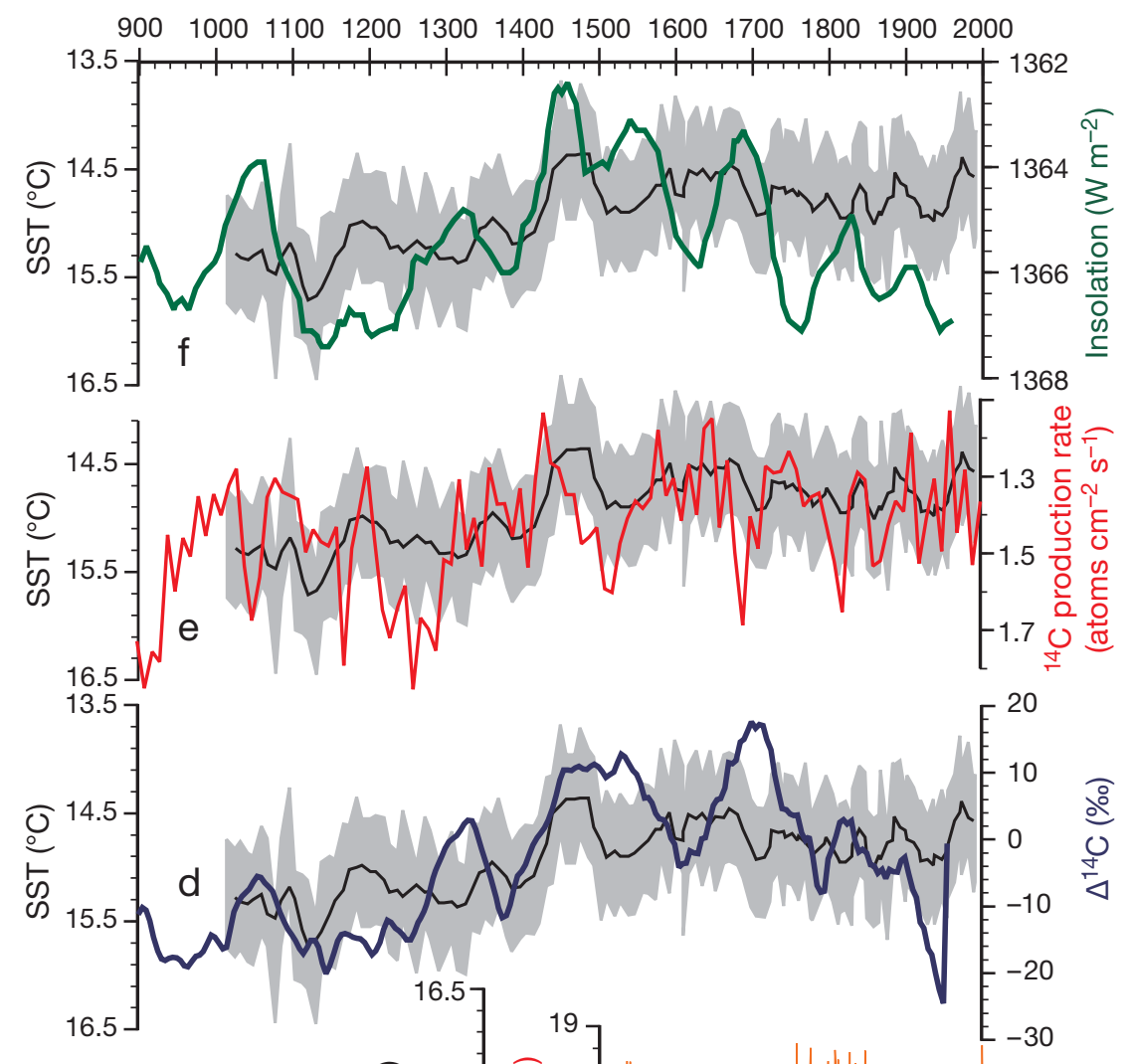

$\mathrm{C} \underbrace{0}_{0}$

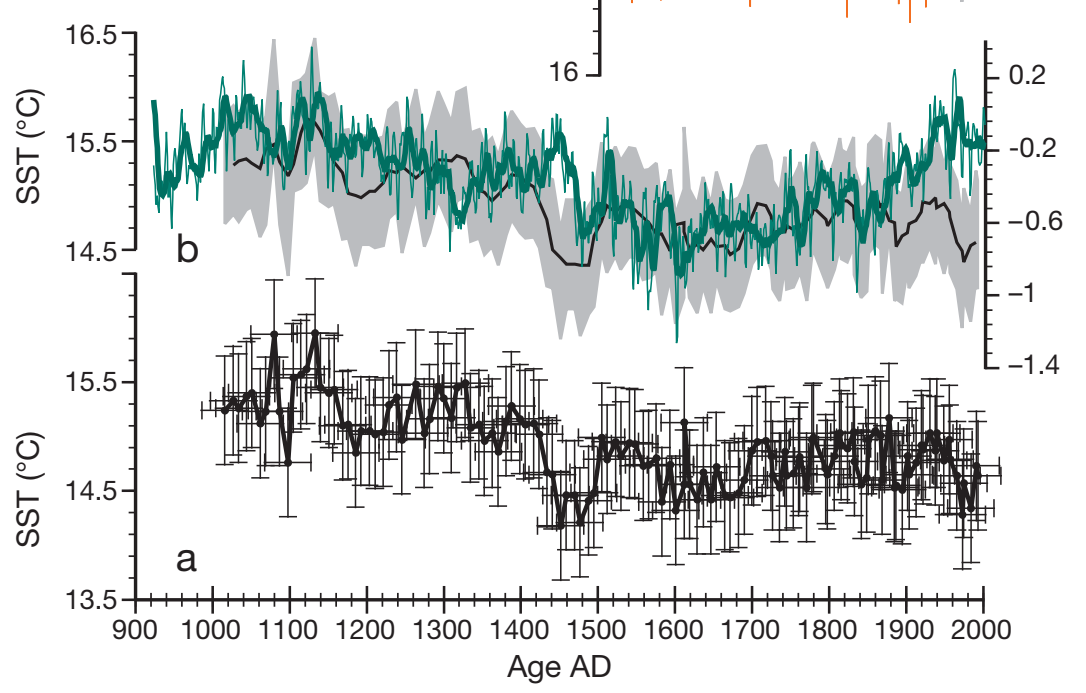

0
0
$\frac{0}{1}$
0
$\frac{0}{0}$
$\frac{0}{0}$
$\frac{0}{2}$
$\frac{0}{0}$
$\frac{1}{1}$
$\frac{1}{0}$
0
$\frac{1}{5}$
$\frac{1}{2}$

Fig. 4. Alkenone-derived sea surface temperature (SST) record for core PO287-6, including (a) both accelerator mass spectrometry ${ }^{14} \mathrm{C}$ (horizontal error bars, $1 \mathrm{SD}$ ) and SST uncertainties (vertical error bars, 1 SD) and (b-f) SST 3-point mean run over error (1 SD) envelope of this data (gray area) in comparison (from the bottom up) to the (b) land-based atmospheric temperature anomaly reconstruction of Moberg et al. (2005), (c) summer (June, July, August) European temperature reconstruction of Luterbacher et al. (2004), (d) Stuiver \& Braziunas's (1989) atmospheric $\delta^{14} \mathrm{C}$ record, (e) Bond et al.'s (2001) raw ${ }^{14} \mathrm{C}$ production series, and (f) Bard et al.'s radionuclide-derived total solar irradiance (Bard et al. 2007) 


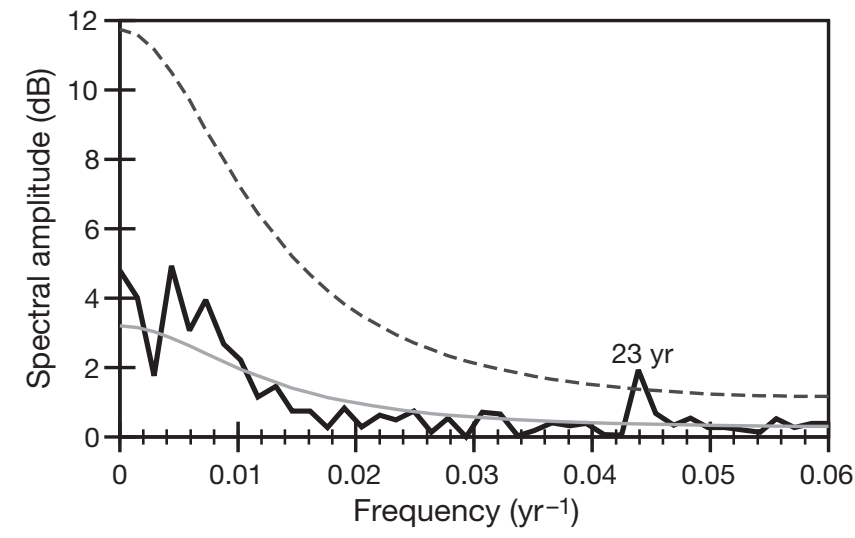

Fig. 5. Bias-corrected spectrum REDFIT (Schulz \& Mudelsee 2002) results for the sea surface temperature (SST) time series (black line). The spectral peak at a period of $23 \mathrm{yr}$ is statistically significant at a $99 \%$ false alarm level (dashed line). AR1 (gray line) is the theoretical model that acts like a null hypothesis to test whether the data variability is a result of 'red noise' bias. Statistical significance of the spectrum is then given by comparing the time series with AR1 under a confidence level value given by a false alarm line

the summer-fall seasonal NAO (data from J. W. Hurrell, Climate Analysis Section, NCAR, Boulder, USA, available at www.cgd.ucar.edu/cas/jhurrell/indices. html; see UCAR - Hurrell; in Table S2 in the supplement). However, to better assess the observed variability, we performed spectral analysis. The obtained power spectrum is dominated by a significant spectral power in the 20-24 yr band (Fig. 5), a period that is common to the insolation records and that can be inferred as a multiple of the known 11 yr Hale solar cycle, which in this case is impossible to grasp due to our record's 10 yr resolution. When our SST record is compared with the mean annual and summer insolation of the last 6 decades, the obtained correlations are quite high ( $\mathrm{r}=0.96$ and 0.84 , respectively; Table S2). This strongly suggests that the processes determining SST variation in the Douro region are in fact responding to long-term solar variability. Cosmogenic isotope $\left({ }^{14} \mathrm{C}\right)$ concentrations are accepted as a solar radiation signal (e.g. Bard et al. 2000, 2007); as such, we also compared our SST record with the various published reconstructed solar radiation data sets (Table S2). Significant negative correlation was found with the Stuiver \& Braziunas (1989) atmospheric $\delta^{14} \mathrm{C}$ record (Fig. 4d), in which production is negatively related to solar activity (Reimer et al. 2004). Positive significant correlations were observed for Bond et al.'s raw ${ }^{14} \mathrm{C}$ production series (Bond et al. 2001; Fig. 4e) and Bard et al.'s radionuclide-derived total solar irradiance (Bard et al. 2007; Fig. 4f). Overall, this hints to insolation as being the ultimate external forcing factor determining SST variation at this site on decadal to secular time scales. The work of Gómez-Navarro et al. (2011) confirms the possibility of simulating the LIA and the MWP in this region as a direct response to radiation forcing.

The increase in atmospheric temperature in the last 200-250 yr is not observed on our SST record. On the contrary, if all the last millennium data are considered and a best-fit line is passed through the data, a decreasing trend in SST in the order of $1^{\circ} \mathrm{C}$ is found (Fig. 6), similar to other high-resolution recently published SST data from the northwestern Atlantic (Gulf of Maine; Wanamaker et al. 2008) and the sub-polar North Atlantic (Hall et al. 2010). The Gulf of Maine SST record shows a $1-2^{\circ} \mathrm{C}$ cooling during the last millennium attributed by Wanamaker et al. (2008) to increased transport and/or cooling of the Labrador Current and decreased Gulf Stream influence. A decrease in the Gulf Stream influence can also explain the decreasing trend observed in this sequence because the PC is a southeastward extension of the North Atlantic Drift, which flows off the Gulf Stream.

Any minor change in the intensity, total flow, position or characteristics of the warm waters that the Gulf Stream transports from the Gulf of Mexico across the Atlantic Ocean will have a direct impact on Western Europe and is likely to be best recorded towards the end of its area of influence than in a more proximal region. Model simulations show that increasing atmospheric temperature result in THC weakening (e.g. Dai

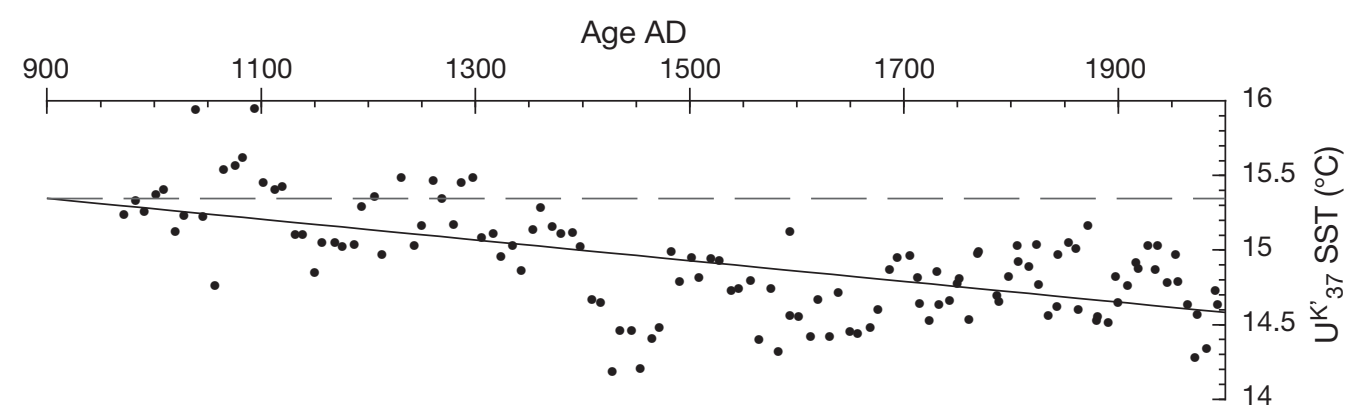

Fig. 6. Alkenone-derived sea surface temperature ( $\left.\mathrm{U}^{\mathrm{K}_{37}^{\prime}} \mathrm{SST}\right)$ vs. AD age. The best-fit line shows the SST decreasing trend of the record to be in the order of $1^{\circ} \mathrm{C}$. The dashed line indicates the temperature difference between the trendline at $\mathrm{AD} 900$ and the present 
et al. 2005) and observational data indicate a weakening of the AMOC (Bryden et al. 2009). Paleo-records and modeling point to a 2-sided effect of a freshwater fill of the North Atlantic, a shift of the Gulf Stream towards lower latitudes and a slowing of the THC. The annual freshwater flux has increased, at least between AD 1990 and 2006 (Thierry et al. 2008). As such, the last 200 to 150 yr's decrease in SST, observed in this Portuguese record as well as in other Iberian margin records (Abrantes et al. 2005b, 2009, Diz et al. 2003), off Iceland (Sicre et al. 2008) and in the sub-polar North Atlantic (Hall et al. 2010), in opposition to the one observed in the atmospheric records, may indeed reflect a decreased influence of the Gulf Stream. This could be manifested as a displacement of the Gulf Stream due to changes in gyre circulation and shape, such as inferred by Thierry et al. (2008) from AD 1990 to 2006 northern North Atlantic CTD and Argo data.

\subsection{River runoff and continental precipitation}

To learn how past changes in the hydrological cycle, such as precipitation and drought, relate to changes in SST is one of the more important aspects for society because, according to the IPCC projections, drought is likely to dominate in Iberia in the near future, and several recent analyses of instrumental data report a trend towards drier conditions in the recent decades in Iberia (e.g. Sousa et al. 2011). River runoff is a function of continental precipitation; therefore, the study of river input indicators combined with instrumental and documentary evidence should help clarify changes in precipitation at times before the existence of instrumental data.

The comparison of the box-core data with instrumentally measured values confirmed our proxies as valid for the Douro River flux (Table S1). MS, although not available for this site box-core, showed a direct relationship with river flow in the Tagus system (Abrantes et al. 2009). Downcore, besides the clear multidecadal variability, these proxies (Fig. $7 \mathrm{a}$,b) indicate an increase in continental precipitation in the LIA and a generally drier MWP, in accordance with the Tagus data set and recent modeling results that do support the idea of a warmer and drier MWP coincident with predominance of a positive NAO and an increase in precipitation during weaker NAO in the colder LIA (Trouet et al. 2009, Goméz-Navarro et al. 2011). After AD 1800, a small decrease is noticed in most continental proxies, but values are still much higher than prior to AD 1500. Another decrease of all these continental components, but now in a continuous mode, is noticed after AD 1950, and likely results from the construction of dams, built mostly between the 1950s and the 1960s (Benito et al. 2005).
The most noticeable events of the record, however, occur at the base of the MWP (AD 1100-1200) and at the onset of the LIA (AD 1400). The co-occurrence of minima in MS and XRF Fe and Ti (Fig. 7a,b) with maxima in large grain-size sediment (Fig. $7 \mathrm{C}$ ) and $\mathrm{C} / \mathrm{N}$ ratio (Fig. 7d) indicate a high-energy flow that transported large quantities of continental-derived material (Stein 1991). The high Ca content in the older event but not in the earlier one is indicative of a different origin for the large particles, and reflects the presence of mollusctype shell fragments possibly transported from the estuary during AD 1100-1200, whereas a non-biogenic origin of the large particles at the AD 1400 event suggests transport of material mostly from the river border lands (Fig. 7e). According to Font Tullot's (1988) analysis of historical documents, both the Douro and Minho Rivers experienced major flooding periods at AD 1088-1094 and AD 1402-1453. These flooding phases, taking into account the AMS ${ }^{14} \mathrm{C}$ age uncertainties of the sediment record $( \pm 25 \mathrm{yr})$, may indeed correspond to the 2 proxy-defined intervals with high continental input and periods of decreasing SST (Fig. 7h).

According to Benito et al. (2005), flood generation, duration and magnitude are strongly correlated to winter precipitation in the Atlantic basins. Trigo et al. (2004) showed that winter rainfall and the Douro River discharge are highly related to years of NAO negative phases. Downcore, the MS and FF are significantly negatively correlated with Hurrell's (1995) NAO index (Table S2). Negative correlation is also observed between the seasonal NAO for November-January and continental input proxies such as the biomarkers of continental plants ([n-alk] and [n-OH]; Table S2) and Luterbacher et al.'s (2002) NAO reconstruction (MS, Fe, phytoliths, freshwater diatoms; Table S2), confirming that the most recent NAO-Douro River flow relationship has been operating for at least the last millennium.

The oscillation in NAO conditions has been related to solar activity, with NAO decreases occurring during maxima of solar activity and increases occurring during periods of decreased solar activity (Kirov \& Georgieva 2002). Nevertheless, on the basis of our record, and considering the reconstruction of solar irradiance of Bard et al. $(2000,2007)$, major storms and flooding in Iberia, at secular time scales, do not happen in ${ }^{14} \mathrm{C}$ minima but during shifts in solar irradiance (Fig. 7f).

\subsection{Primary productivity and coastal upwelling}

Coastal upwelling processes respond to changes in wind direction and are then subjected to strong vari- 


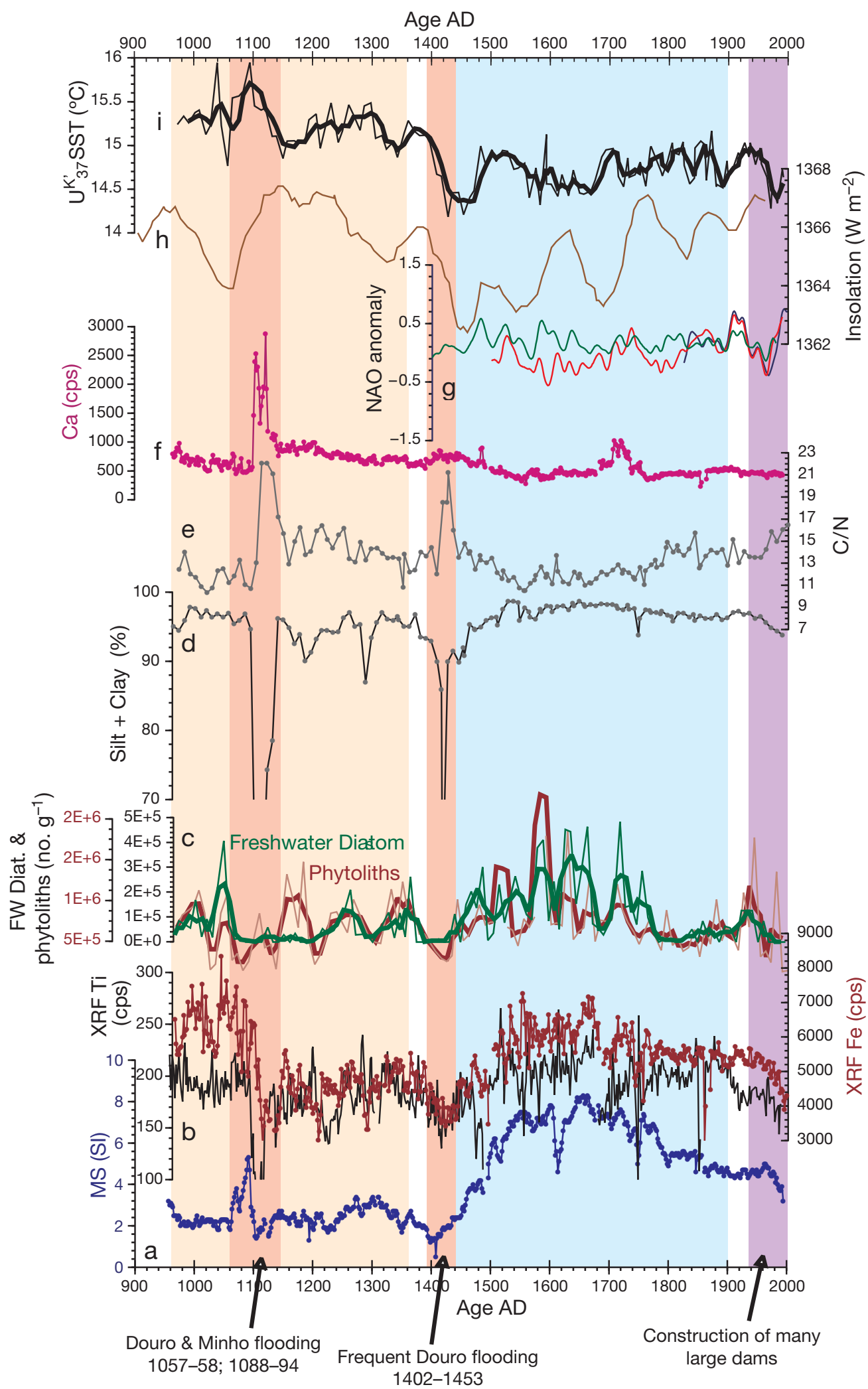

Fig. 7. Record of the continental/river input proxies (from the bottom up): (a) magnetic susceptibility (MS); (b) Fe and Ti abundance determined by X-ray fluorescence (XRF, in counts $\mathrm{s}^{-1}$ [cps]); (c) freshwater (FW) diatom and phytolith abundance; (d) abundance of sediment's fine fraction; (e) C/N ratio; (f) Ca abundance determined by XRF; (g) instrumental NAO index (black line), Luterbacher reconstruction (red line; Luterbacher et al. 2002) and Cook reconstruction (green line; Cook et al. 2002); (h) Bard et al.'s (2007) radionuclide-derived total solar irradiance; and (i) alkenone-derived sea surface temperature ( $\mathrm{U}^{\mathrm{K}}{ }_{37} \mathrm{SST}$ ). Thick lines represent a 3point running mean. Vertical light orange bands mark the Medieval Warm Period; the blue band marks the Little Ice Age; darker orange bands specify the periods for which the depicted proxies indicate strong storm/flooding events; and the violet interval marks the continuous decrease of the continental input proxies depicted in $(\mathrm{a}-\mathrm{c})$ and $(\mathrm{f})$ records 
ability (Barber \& Smith 1981) and are highly vulnerable to changes in climate. Furthermore, coastal upwelling areas are the most productive areas of the modern ocean, but the pulsed input of new nutrients influences the composition and temporal variability of the primary producers and, consequently, the entire pelagic food web (Peinert et al. 1989). Subsequently, changes in coastal upwelling areas can have a profound impact on the global biological production and the world's economy through its control on fish stocks.

Marine diatom abundance and dominance of the assemblage by species of the genus Chaetoceros are well-accepted proxies of upwelling-generated high productivity (Estrada \& Blasco 1985) and in our correlation exercise (Table S1), they do reveal strong correlations with upwelling intensity in fall and the summer/upwelling season. Coccolithophores, in contrast, are known to be the dominant phytoplankters in winter and in stratified waters (e.g. Margalef 1978, Moita 2001).

Fig. 8a shows the main diatom component abundance, the sediment TOC (Fig. 8c) and total alkenone (Fig. 8d) concentrations. The relationships among these proxies should give information about the phytoplankton community composition and shed light on the dominant process behind primary production at any one time. Despite the high magnitude of variation observed for TOC (Fig. 8c), the co-occurrence of its higher values with the high diatom abundance and assemblage dominance by the genus Chaetoceros points to stronger or more persistent summer upwelling conditions during the MWP with the exception of the first flooding warm period discussed in the previous section. The LIA's stepwise decrease in TOC and lower maxima in diatom abundance indicate relatively lower upwelling-related productivity. However, AD $1560-1730$ is marked by a rise in diatoms. This period is within the interval characterized by the occurrence of several drought episodes affecting in the whole Iberian Peninsula (Domínguez-Castro et al. 2010) at times of NAO+ conditions in Cook's NAO reconstruction (Fig. 8g; Cook et al. 2004) and may thus represent the occurrence of coastal upwelling within the LIA's generally more weak NAO.

After AD 1730, diatom and Chaetoceros abundances show a decreasing tendency up to the present day, whereas the abundance of alkenone-producing coccolithophores shows an increasing tendency and the TOC content is maintained (Fig. 8a,c,d). A decrease in summer/annual upwelling conditions may be deduced from the diatom data, but primary productivity is maintained, as shown by the TOC record. As such, a shift of the phytoplankton community towards a dominance of coccolithophores over diatoms must have occurred. Such data indicate a change in the process generating primary productivity and imply a shift in the water col- umn structure towards more stratification (Margalef 1978). However, most proxies for continental-derived material show a slight decrease in total flux (Fig. 7) and SST shows no significant change (Fig. 8e). As such, to understand what might have changed, we need to investigate the water column conditions.

\subsection{Water column structure}

The history of the water column structure is approached by stable isotope analysis of 3 planktonic foraminifera species (Globigerina bulloides, G. inflata and Neogloboquadrina pachyderma; Fig. 8f) described in the literature as either living at different seasons and/or at different depths of the water column (e.g. Fischer \& Wefer 1999). As any other proxy, its regional calibration is needed, but no trap and/or water column data are yet available. However, Salgueiro et al.'s (2008) surface sediment spatial distribution of species unveils $G$. bulloides as the coastal upwelling species, $N$. pachyderma var. dextral as a winter deep-dwelling species linked with the Portugal Current and G. inflata as associated to the wintertime eastern branch of the Azores Current. Our correlation exercise (Table S1) confirms G. bulloides' relationship to upwelling intensity during the upwelling season, through the negative correlation to its $\delta^{18} \mathrm{O}$, and reveals a negative correlation of the benthic Uvigerina $\delta^{18} \mathrm{O}$ with winter upwelling.

The $\delta^{18} \mathrm{O}$ downcore results of higher variability of Globigerina bulloides during the MWP as opposed to the LIA can be interpreted as an indication of a stronger upwelling variability during the MWP. Moreover, all planktonic species show variability around an otherwise similar mean value throughout the record up to the 18th century (AD 1730), the time at which the 3 records show a tendency to separate from each other, with $G$. bulloides becoming slightly less positive, and G. inflata and Neogloboquadrina pachyderma var. dextral departing towards more positive values (Fig. 8e). Also at this time, the Uvigerina $\delta^{18} \mathrm{O}$ record (Fig. 8f) shows a spike towards more positive values between $\mathrm{AD} 1740$ and $\mathrm{AD}$ 1750, which can be associated with an important change in winter upwelling conditions. From Fig. 6 we can also see the co-occurrence of $\mathrm{MS}, \mathrm{Fe}, \mathrm{Ti}$ and $\mathrm{Ca}$ minima, but there is no major change in $\mathrm{FF}$ or $\mathrm{C} / \mathrm{N}$ (Fig. $7 \mathrm{~d}, \mathrm{e}$ ) or in the various microorganisms as seen for the abovedescribed flooding events. On the basis of these results, these sediments cannot be attributable to sediment disturbances. On the contrary, the above data support a decrease in precipitation and river input of fine sediments, accompanied by a slight increase in sand and Ca content possibly resulting from the sandsized foraminiferal $\mathrm{CaCO}_{3}$ shells. 


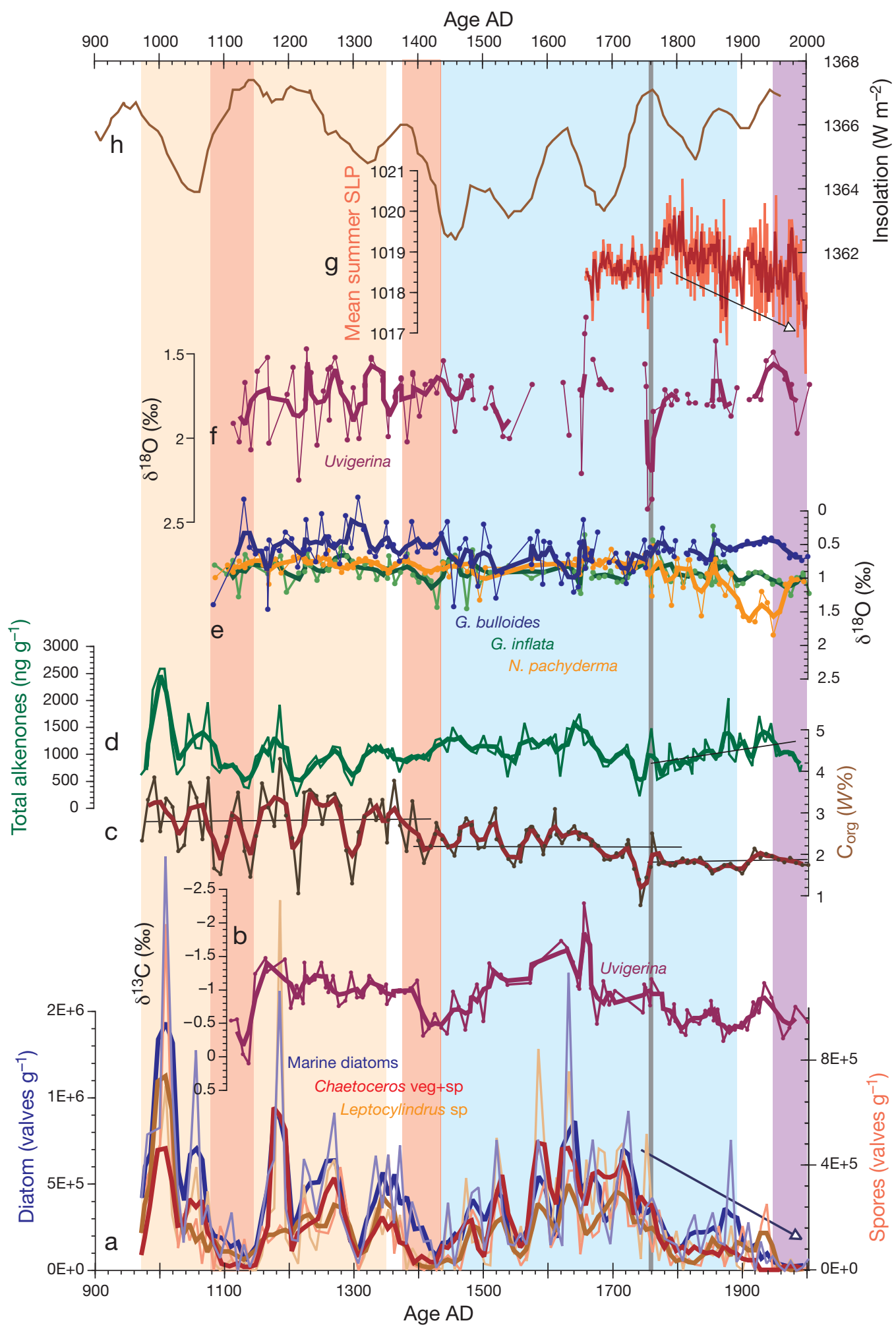

Fig. 8. Proxy records for primary productivity and water-column structure (from the bottom up): (a) abundance of marine diatoms, Chaetoceros spp. and Leptocylindrus spp. (the color of the species name relates to the respective record); (b) $\delta^{13} \mathrm{C} U v i g e r i n a ~ s p$. $(\% \text { VPDB })_{i}(\mathrm{c})$ total organic carbon $\left(\mathrm{C}_{\text {org }}\right)$ content expressed in percent weight $(W \%)_{i}(\mathrm{~d})$ total alkenone content; (e) planktonic foraminifera $\delta^{18} \mathrm{O}$ records (\% VPDB); (f) Uvigerina $\delta^{18} \mathrm{O}$ record (\% VPDB); (g) mean summer sea level pressure (SLP) reconstruction (Luterbacher et al. 2002); and (h) Bard et al.'s (2007) radionuclide-derived total solar irradiance. Thick lines represent a 3point running mean. Arrows in panels a and $g$ highlight declining trends; black line in d indicates a rising trend. Horizontal black lines in $\mathrm{c}$ indicate levels around which data vary during the respective interval. Colored bands are as in Fig. 7 . The vertical gray line at AD 1760 marks the boundary after which proxy records at site PO287-6 start to diverge from the general prior trends 
As a whole, the above-described results imply similar seasonality and/or persistent mixed water column conditions. Based on the present-day observations of Vitorino et al. (2002) and Oliveira et al. (2007), this suggests the dominance of strong winter mixing and/or summer upwelling turbulence for AD 900-1730, followed by a transition period between $\mathrm{AD} 1730$ and AD 1740 marked by dry winter conditions. Under the present interglacial conditions and with no indication of considerable changes in river flux within the last $\pm 300 \mathrm{yr}$, this radical change at the end of the LIA may reveal: (1) changes in the seasonality of the main oceanographic processes; (2) the presence of water masses with different thermohaline properties; and (3) changes in the oceanic circulation pattern.

Vitorino et al. (2002) and Oliveira et al. (2007) show that episodic fall-winter upwelling events result in thermal stratification in the upper water column. Additionally, the analysis of $40 \mathrm{yr}$ of data (AD 1967-2006) has shown that the number of such events has increased in the last decade, whereas the total annual and summer upwelling intensity is decreasing (Alvarez et al. 2008, Gómez-Gesteira et al. 2008).

At present, the circulation pattern favourable to the occurrence of winter trade winds at the low latitudes of the North Atlantic is explained by an intensification of the polar atmospheric circulation and more pronounced Icelandic Low and Azores High, that is, a positive NAO index (Hurrell 1995). The AD 1730-1740 transition, marked by fine terrigenous and a positive $\delta^{18} \mathrm{O}$ Uvigerina spike, coincides with a drought period that mainly affects the Atlantic sector of the Iberian Peninsula (Domínguez-Castro et al. 2010). The suite of reconstructions and extended NAO records (Cook et al. 2002, Luterbacher et al. 2002, Vinther et al. 2003) indicate AD 1730-1740 as an NAO maximum interval followed by a slightly positive NAO up to AD 1850 (Fig. $7 \mathrm{~g}$ ). Of note is the fact that, as for the flooding events, this major drought mark occurs during a transition in insolation (Fig. 7h).

If the relationship between proxies and 'forcing factors' is considered (Table S2), both Globigerina bulloides and Neogloboquadrina pachyderma $\delta^{18} \mathrm{O}$ show a strong but opposite signal correlation with instrumental insolation, as well as reconstructions (Table S2). $N$. pachyderma var. dextral $\delta^{18} \mathrm{O}$ is significantly related to winter upwelling intensity (Table S1) and shows a positive relationship with the winter SeptemberNovember and October-December UCAR NAO index (calculated by J. W. Hurrell, Climate Analysis Section, NCAR, Boulder, USA, available at www.cgd.ucar.edu/ cas/jhurrell/indices.html; see UCAR-Hurrell in Table S2). The opposite evolution of these 2 planktonic foraminifera $\delta^{18} \mathrm{O}$ records is then compatible with the increasing tendency in total insolation (Fig. 8h) and

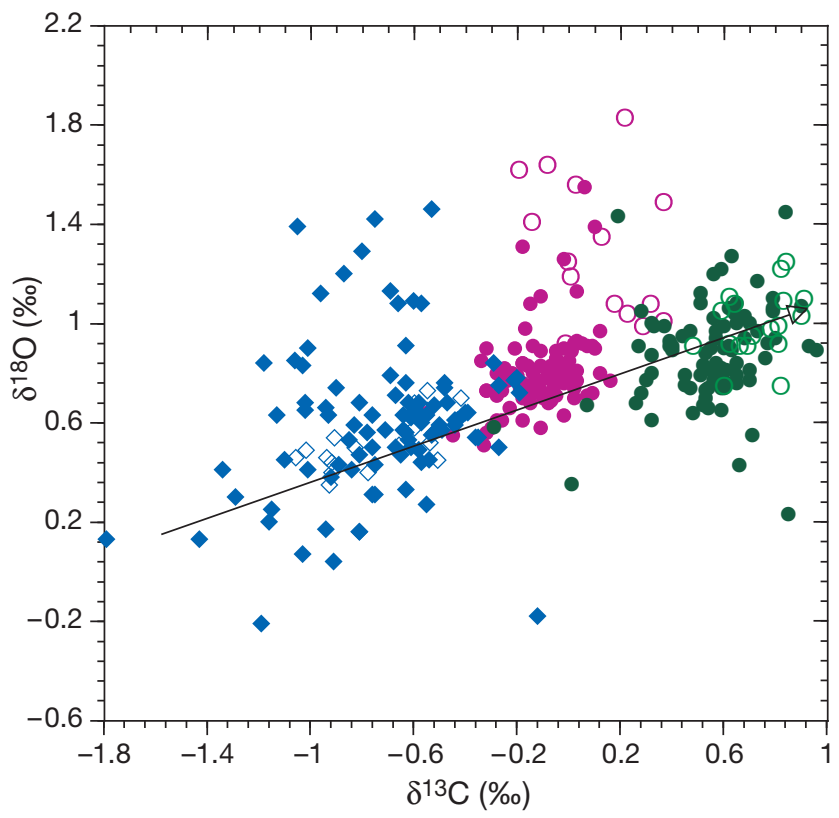

Fig. 9. $\delta^{18} \mathrm{O}$ vs. $\delta^{13} \mathrm{C}$ (\% VPDB) of planktonic foraminifera species Globigerina bulloides (blue), G. inflata (green), Neogloboquadrina pachyderma var. dextral (purple) for the periods before (filled) and after (open) AD 1850. Planktonic foraminifera $\delta^{18} \mathrm{O}$ is a proxy for sea surface temperature; planktonic foraminifera $\delta^{13} \mathrm{C}$ is used as a proxy for the water mass nutrient content

more positive winter NAO conditions leading to more frequent and/or stronger winter upwelling events, a hypothesis favored also by the decreasing tendency in the minima of the mean summer SLP in the area (Fig. 8g; Luterbacher et al. 2002).

Stronger and/or more frequent winter upwelling is also suggested by the replacement of Neogloboquadrina pachyderma var. dextral by N. pachyderma var. sinistral, a variety generally associated with the very cold subpolar waters in sediments younger than $A D$ 1950. An increase in winter upwelling in this northernmost site of the Portugal-Canary current system where upwelling is seasonal would also help to explain an increase in the mean annual upwelling off NW Africa where coastal upwelling is persistent (McGregor et al. 2007). But, is there a possibility for an associated change in water masses?

Water masses are identified on the basis of their temperature and salinity, but the nutrient content of upwelling source waters is a determinant of the level of biological response (Barber \& Smith 1981). One way to verify the occurrence of changes in water mass is through analyses of the isotopic composition of the different planktonic foraminifera species, as $\delta^{18} \mathrm{O}$ should monitor SST and $\delta^{13} \mathrm{C}$ the nutrient content/utilization of the different water masses each species lives in. Fig. 9 shows a plot of the relationship between those 
characteristics before and after AD 1850; noticeable changes are evident in Globigerina inflata $\delta^{13} \mathrm{C}$ and Neogloboquadrina pachyderma $\delta^{13} \mathrm{C}$ and $\delta^{18} \mathrm{O}$, which become higher after AD 1850.

Although different $\delta^{13} \mathrm{C}$ values indicate water masses with different nutrient contents, the possibility that changes in $\delta^{13} \mathrm{C}$ towards higher ${ }^{13} \mathrm{C}$ values are caused by increased ${ }^{12} \mathrm{C}$ consumption due to higher primary production needs to be considered (Curry \& Crowley 1987). Besides the main productivity proxies previously considered, the $\delta^{13} \mathrm{C}$ signal of an infaunal benthic foraminifera species can also be used as an independent indicator of primary production because it conveys the nutrient state of the sediment's interstitial waters, which is a function of the amount of ${ }^{12} \mathrm{C}$ liberated by the oxidation of TOC within the top sediment layer (McCorkle \& Emerson 1988). The Uvigerina $\delta^{13} \mathrm{C}$ record (Fig. 9c) validates the indication of decreased annual primary production after AD 1850 as well as during the LIA (with the exception of AD 1560-1680). If the $\delta^{13} \mathrm{C}$ changes cannot be explained by increased production, then differences in different water masses and/or changes in circulation patterns are implied.

At present, the upwelled water source is the Eastern North Atlantic Central Water of subpolar origin, which is formed by winter cooling in the eastern North Atlantic (McCartney \& Talley 1982, Rios et al. 1992). The increase in nutrient content suggested by the Neogloboquadrina pachyderma $\delta^{13} \mathrm{C}$ would certainly be another favorable factor for higher primary productivity conditions in winter. However, both $N$. pachyderma, the winter species related to the PC, and Globigerina inflata, the IPC species, show alterations in their $\mathrm{C}$ and $\mathrm{O}_{2}$ isotopic signals after $\mathrm{AD}$ 1850 ; the presence of $N$. pachyderma points to winter changes in the water mass being advected from the subpolar/northeastern Atlantic, and the presence of $G$. inflata suggests co-occurring alterations in the lowlatitude Atlantic circulation as well, and the transport of more ${ }^{13} \mathrm{C}$-rich waters from the Azores Current by the IPC in winter. This information can only be reconciled if changes in the circulation of the North Atlantic are considered.

\subsection{North Atlantic circulation}

The AMOC is an important component of the climate system; $_{i}$ it contributes to the heat transport into the North Atlantic and its fluctuations have a major influence on climate at decadal time scales (Ganachaud \& Wunsch 2003). Additionally, model simulations suggest that North Atlantic SST variation is a reflection of the AMOC and link it to changes in the AMO. Gray et al. (2004) confirmed the AMO as a consistent compo- nent of the North Atlantic climate for the past 5 centuries (Fig. 10b). In other words, the path and strength of the westerlies influence the Sargasso Sea convection, which, in turn, is in phase with deep-water formation and the spreading of Gulf Stream waters northwards and eastwards (Delworth \& Mann 2000). Stronger westerly winds can therefore result in heat loss to the atmosphere, and a decline in the AMOC and THC, which led Lund et al. (2006) to suggest it as the possible reason behind the colder conditions felt during the LIA.

The relationship between stronger westerlies and the Gulf Stream spread into the northeast Atlantic was supported by Keigwin \& Pickart (1999) on the basis of century-scale changes in SST observed both in the Bermuda Rise and the Labrador Shelf off NW Africa (deMenocal 2001; Fig. 10c,d,g). More recently, higher resolution temperature records from sites positioned along the Gulf Stream pathway have allowed further investigation of the translation of past GS activity to the east Atlantic. Off northwest Iceland, Sicre et al. (2008) (Fig. 10e) confirmed that SST reflects the ocean response to wind forcing and the NAO. Evidence for a decadal-scale coupling between surface and deep-ocean variability over the past $230 \mathrm{yr}$, also possibly driven by the NAO, comes from a subpolar northeast Atlantic high-resolution record (Hall et al. 2010). Diatom-derived SST from this same site shows a negative correlation with NAO, i.e. cold SST for positive NAO. A relationship that the authors attribute to wind-driven variations in the summer flux volume of North Atlantic surface water (Miettinen et al. 2010). Gray's reconstructed AMO and our SST record show no significant correlation, and the same is true for the various foraminiferal isotopic records (Table S2). However, the comparison of the AMO and SST records shows coherency for the period after AD 1850, and when correlations are calculated for AMO vs. the SST and stable isotope data for after AD 1850 $(\mathrm{n}=22$ and $\mathrm{p}>0.05)$, the correlation with SST and the nutrient utilization proxy $\left(\delta^{13} \mathrm{C}\right.$ of the various planktonic foraminifera) becomes significant. For SST, Neogloboquadrina pachyderma $\delta^{13} \mathrm{C}$ and Globigerina inflata $\delta^{13} \mathrm{C}$, the correlation is positive $(\mathrm{r}=0.37,0.40$ and 0.27 , respectively), whereas G. bulloides $\delta^{13} \mathrm{C}$ shows a negative correlation $(r=-0.39)$. What could cause these previously unrelated records to become correlated after $\mathrm{AD}$ 1850? Can it be an indication that AMO has an anthropogenic origin, as defended by Mann \& Emanuel (2006)?

Enfield \& Cid-Serrano (2010) did a careful review of the literature dealing with the AMO and the ongoing discussion on its anthropogenic or natural origin, and conclude that (p. 1, abstract) 'the AMO is probably comprised of both natural and anthro- 


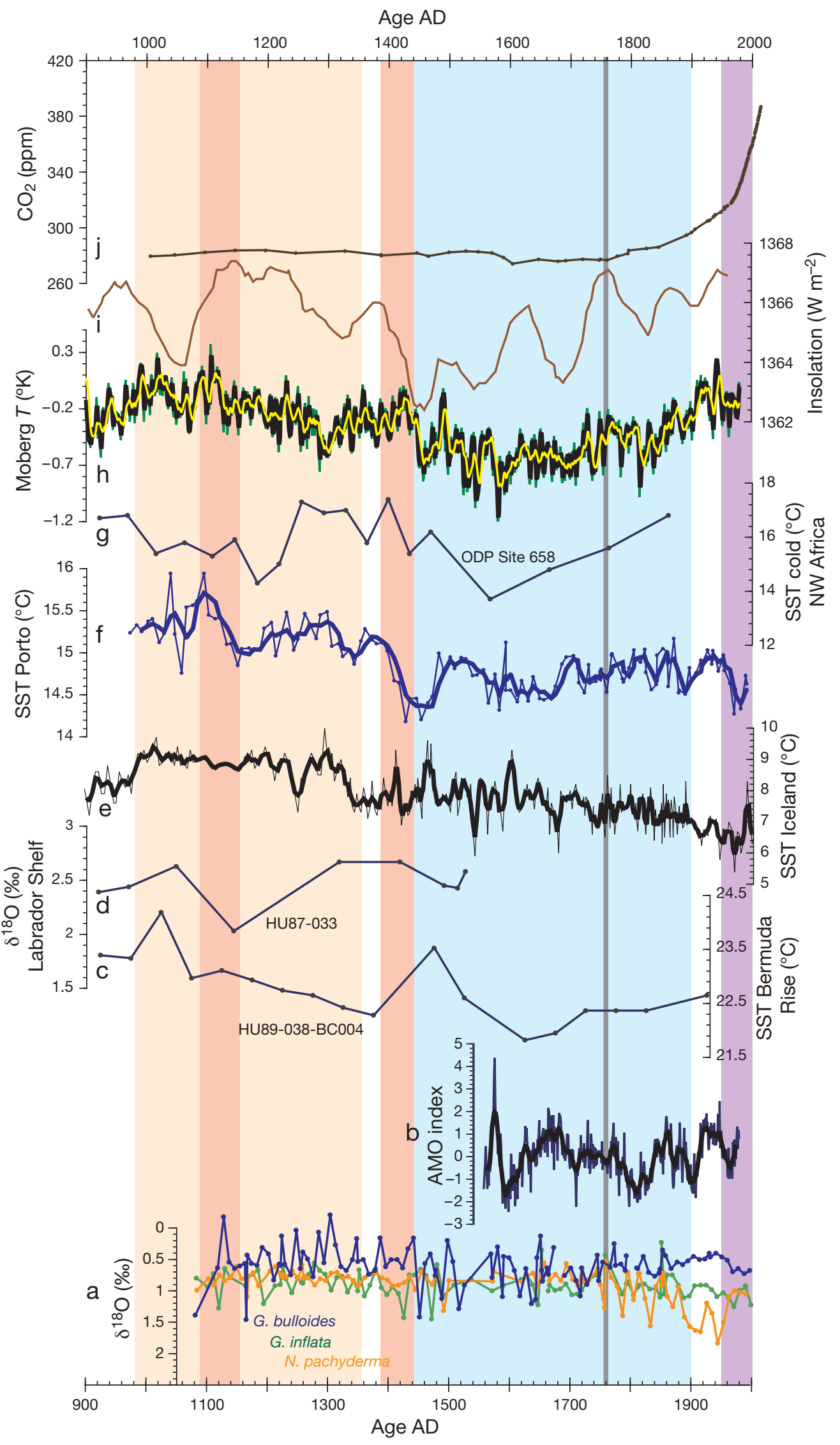


pogenic forcing in ways that preclude a physically based separation of the two, using the limited historical data sets.' Hence, proxy data analysis is absolutely essential to help elucidate the AMO's origin. Besides, its direct influence on the North Atlantic circulation, as well as the Gulf Stream strength and latitudinal position, is most certainly translated into the Iberian margin by the $\mathrm{PC}$, the eastern equatorward branch of the Gulf Stream. Our isotopic data suggest major alterations mainly in wintertime, with a southeastward drift of colder and nu- trient-enriched waters from the Gulf Stream via the $\mathrm{PC}$, at the same time as more nutrient-rich waters are advected from the subtropical Atlantic via the Azores Current. The suggestion that variation in tropical salinity combined with changes in tropical surface circulation is involved in the mechanism behind multidecadal variations in overturning circulation has been advanced by Kilbourne et al. (2008).

The timing of such modification(s) in oceanic circulation, 350-300 yr ago, coincides with a decreasing tendency in SST shown by the high-resolution records (Fig. 10e,f) (Hall et al. 2010), and indicates a departure from its co-occurrence with Moberg et al.'s (2005) landbased temperature reconstruction (Fig. 10h), Bard et al.'s (2007) total solar irradiance (Fig. 10i) and the beginning of the recent rise in atmospheric $\mathrm{CO}_{2}$ (Etheridge et al. 1996; Fig. 10j). Although paleo-data alone cannot distinguish between natural and nonnatural forcing for the $\mathrm{AMO}$, our data suggest that changes in the North Atlantic circulation start around AD 1730 and become important at AD 1850. Because this is the timing at which the actual rise in atmospheric $\mathrm{CO}_{2}$ and $\mathrm{CH}_{4}$ content is noted in the Greenland ice-core records, it favours a strong anthropogenic influence in line with the proposition of Mann \& Emanuel (2006).

\section{CONCLUSIONS}

The objective of this study was to identify the local (N Portugal) reactions to hemispheric climate variations. Although this is a single and very localized record, its location in the European region with the highest correlation to NAO indicates its importance.

Results suggest that climate changes for the period $\mathrm{AD} 900$ to the present occur in accordance with the Northern Hemisphere trends and are mainly modulated by NAO and insolation at the decadalcentennial scale.

SST extremes occurred right at the beginning of both the MWP and the LIA, historic climatic periods that are identifiable by the persistence in average SST.

The LIA appears as a period of higher precipitation than the MWP, but abnormal precipitation events resulting in flooding are marked at AD 1100-1200 (early MWP) and AD 1400 (MWP-LIA transition), times of well-marked SST decreases and shifts in solar activity.

The history of the water column structure, as revealed by the stable isotope records of 3 planktonic foraminifera (Globigerina bulloides, G. inflata and Neogloboquadrina pachyderma), shows a separation of the various planktonic foraminifera $\delta^{18} \mathrm{O}$ records that starts at AD 1730, but becomes clear at AD 1850. The concomitant switch in phytoplankton community structure suggests a continuous decrease in annual upwelling but an increase in winter upwelling conditions.

The AD 1850 shift in upwelling conditions coincides with an increase in coherence between our data and the AMO index, suggesting that the local coastal upwelling changes, which are determined by the control of the NAO over the hemispheric atmospheric circulation (wind direction and strength), are connected with the North Atlantic Ocean's surficial and thermohaline circulation.

The fact that the coherence between AMO and our records vanishes beyond AD 1850, and that the AMO has been hypothesized to be the result of important anthropogenic forcing, supports the existence of a strong anthropogenic effect on the large-scale north Atlantic circulation and raises imperative questions about the real value of the use of the instrumental record as the sole calibration data set for climate reconstructions, as it may not be a good analogue for the preAD 1730 conditions.

Fig. 10. (a) Planktonic foraminifera $\delta^{18} \mathrm{O}$ records (\% VPDB) as water-column structure proxies compared to the (from the bottom up): (b) Atlantic Multidecadal Oscillation (AMO) reconstruction of Gray et al. (2004); (c) Bermuda Rise sea surface temperature (SST) estimated from the planktonic foraminifera Globigerina ruber $\delta^{18} \mathrm{O}$ values (sediment core HU89-038-BC004; Keigwin 1996); (d) Laurentian fan planktonic foraminifera $\delta^{18} \mathrm{O}$ as a proxy for SST, higher $\delta^{18} \mathrm{O}$ implies colder SST (sediment core HU87-033; Keigwin \& Pickart 1999); (e) North Iceland alkenone-derived SST (Sicre et al. 2008); (f) alkenone-derived SST of PO287-6; (g) NW Africa cold season SST derived from the planktonic foraminifera fauna (ODP Site 658; deMenocal 2001); (h) land-based atmospheric temperature $(T)$ anomaly reconstruction of Moberg et al. (2005) with the original data as light green line, 3-yr running mean in black and 10-yr running mean in yellow; (i) Bard et al.'s radionuclide-derived total solar irradiance (Bard et al. 2007); and (j) Law Dome (Etheridge et al. 1996) and Mauna Loa atmospheric $\mathrm{CO}_{2}$ records (ppm). Thick lines in b, e and $\mathrm{f}$ indicate 3-point running means. Colored bands are as in Fig. 7 and the AD 1760 gray line is as in Fig. 8 
Acknowledgements. The authors thank the financial support of LNEG, FCT through project INGMAR and fellowships SFRH/BD/13749/2003, SFRH/ BPD/21691/2005, and the Università degli Studi di Genova as promoter of the Communities' Leonardo da Vinci programme in Italy. We thank our English-speaking colleague Z. Stroynowski for the language revision as well as the marine geology laboratory personnel and the Capitan and crew of RV 'Poseidon' cruise PO287 for their important contributions. We are also grateful to $\mathrm{M}$. Mil-Homens for doing the XRF measurements, and 2 anonymous reviewers that greatly helped to improve an earlier version of the manuscript.

\section{LITERATURE CITED}

Abrantes F (1988) Diatom assemblages as upwelling indicators in surface sediments in Portugal. Mar Geol 85:15-39

Abrantes F, Moita T (1999) Water column and recent sediment data on diatoms and coccolithophorids, off Portugal, confirm sediment record as a memory of upwelling events. Oceanol Acta 22:319-336

Abrantes F, Gil I, Lopes C, Castro M (2005a) Quantitative diatom analyses: a faster cleaning procedure. Deep-Sea Res Part II 52:189-198

Abrantes F, Lebreiro S, Rodrigues T, Gil I and others (2005b) Shallow-marine sediment cores record climate variability and earthquake activity off Lisbon (Portugal) for the last 2000 years. Quat Sci Rev 24:2477-2494

Abrantes F, Alt-Epping U, Lebreiro S, Voelker A, Schneider R (2008) Sedimentological record of tsunamis on shallow-shelf areas: the case of the $1969 \mathrm{AD}$ and $1755 \mathrm{AD}$ tsunamis on the Portuguese Shelf off Lisbon. Mar Geol 249:283-293

> Abrantes F, Lopes C, Rodrigues T, Gil I, Witt L, Grimalt J, Harris I (2009) Proxy calibration to instrumental data set: implications for paleoceanographic reconstruction. Geochem Geophys Geosyst 10:Q09U07 doi:10.1029/2009gc 002604

Alvarez I, Gomez-Gesteira M, deCastro M, Dias JM (2008) Spatiotemporal evolution of upwelling regime along the western coast of the Iberian Peninsula. J Geophys Res 113:C07020 doi:10.1029/2008JC004744

Bakun A (1973) Coastal upwelling indices, west coast of North America, 1946-1971. NOAA Tech Rep NMFS SSRF-671

Barber R, Smith R (1981) Coastal upwelling ecosystems. In: Longhurst AR (ed) Analysis of marine ecosystems. Academic Press, New York, NY, p 31-68

Bard E, Raisbeck G, Yiou F, Jouzel J (2000) Solar irradiance during the last 1200 years based on cosmogenic nuclides. Tellus B Chem Phys Meterol 52:985-992

Bard E, Raisbeck G, Yiou F, Jouzel J (2007) Comment on 'Solar activity during the last $1000 \mathrm{yr}$ inferred from radionuclide records' by Muscheler et al. (2007). Quat Sci Rev 26:2301-2308

Benito G, Barriendos M, Llasat MC, Machado MJ, Thorndycraft VR (2005) Impacts on natural hazards of climatic origin. A. Flood risk. In: Moreno JM (ed) Preliminary evaluation of the impacts of climate change in Spain. Ministerio de Medio Ambiente, Madrid, pp. 507-527, available at www.mma.es/oecc/impactos.htm.

Bianchi GG, McCave IN (1999) Holocene periodicity in North Atlantic climate and deep-ocean flow south of Iceland. Nature 397:515-517
Bond G, Kromer B, Beer J, Muscheler R and others (2001) Persistent solar influence on North Atlantic climate during the Holocene. Science 294:2130-2136

Bryden HL, Mujahid A, Cunningham SA, Kanzow T (2009) Adjustment of the basin-scale circulation at $26^{\circ} \mathrm{N}$ to variations in Gulf Stream, deep western boundary current and Ekman transports as observed by the Rapid array. Ocean Sci 5:421-433

Cabeçadas G, Brogueira MJ, Coutinho T, Oliveira AP (2008) Impact of hydrodynamics on the ecology of Douro coastal waters. European Geophysical Union General Assembly. EGU, Vienna, SRef-ID 1607-7962/gra/EGU2008-A-08475

> Cook ER, D'Arrigo RD, Mann ME (2002) A well-verified, multiproxy reconstruction of the winter North Atlantic Oscillation index since A. D. 400. J Clim 15:1754-1764

Cook ER, Esper J, D'Arrigo RD (2004) Extra-tropical Northern Hemisphere land temperature variability over the past years. Quat Sci Rev 23:2063-2074

Curry W, Crowley $\mathrm{T}$ (1987) The delta ${ }^{13} \mathrm{C}$ of equatorial Atlantic surface waters: implications for Ice Age $\mathrm{pCO}_{2}$ levels. Paleoceanography 2:489-518

> Curry R, Mauritzen C (2005) Dilution of the northern North Atlantic Ocean in recent decades. Science 308:1772-1774

Dai A, Hu A, Meehl GA, Washington WM, Strand WG (2005) Atlantic thermohaline circulation in a coupled general circulation model: unforced variations versus forced changes. J Clim 18:3270-3293

> Debret M, Sebag D, Crosta X, Massei N, Petit J-R, Chapron E, Bout-Roumazeilles V (2009) Evidence from wavelet analysis for a mid-Holocene transition to global climate forcing. Quat Sci Rev 28:2675-2688

> Delworth TL, Mann ME (2000) Observed and simulated multidecadal variability in the Northern Hemisphere. Clim Dyn 16:661-676

deMenocal PB (2001) Cultural responses to climate change during the Late Holocene. Science 292:667-673

> Dias JMA, Gonzalez R, Garcia C, Diaz-del-Rio V (2002) Sediment distribution patterns on the Galicia-Minho continental shelf. Prog Oceanogr 52:215-231

Dickson RR, Brown J (1994) The production of North Atlantic Deep Water: sources, rates, and pathways. J Geophys Res 99:12,319-12,341

Diz P, Francés G, Pena L, Nombela MA, Alejo I (2003) Benthic Foraminifera response to Holocene environmental changes in the Ría de Muros (NW Spain). EGS-AGUEUG Joint Assembly, Nice, France, 6-11 April 2003, abstract \#13541

> Domínguez-Castro F, García-Herrera R, Ribera P, Barrien$\operatorname{dos} M(2010)$ A shift in the spatial pattern of Iberian droughts during the 17th century. Clim Past 6:553-563

Enfield DB, Cid-Serrano L (2010) Secular and multidecadal warmings in the North Atlantic and their relationships with major hurricane activity. Int J Climatol 30:174-184

Esper J, Cook ER, Schweingruber FH (2002) Low-frequency signals in long tree-ring chronologies for reconstructing past temperature. Science 295:2250-2253

Estrada M, Blasco D (1985) Phytoplankton assemblages in coastal upwelling areas. In: Bas C, Margalef R, Rubies P (eds) Simposio Internacional sobre las areas de afloramiento mas importantes del oeste Africano. (Cabo Blanco y Benguela). Instituto de Investigaciones Pesqueras, Barcelona, p 379-402

Etheridge DM, Steele LP, Langenfelds RL, Francey RJ, Barnola JM, Morgan VI (1996) Natural and anthropogenic changes in atmospheric $\mathrm{CO}_{2}$ over the last 1000 
years from air in Antarctic ice and firn. J Geophys Res 101:4115-4128

Fischer G, Wefer G (1999) Use of proxies in paleoceanography: examples from the South Atlantic. Springer, Berlin

Folland CK, Knight J, Linderholm HW, Fereday D, Ineson S, Hurrell JW (2009) The summer North Atlantic oscillation: past, present, and future. J Clim 22:1082-1103

Font Tullot I (1988) Historia del clima de España. Spanish Meteorological Institute (INM), Madrid

Gan J, Lu Z, Dai M, Cheung AYY, Liu H, Harrison P (2010) Biological response to intensified upwelling and to a river plume in the northeastern South China Sea: a modeling study. J Geophys Res 115:C09001 doi:10.1029/ 2009JC005569

> Ganachaud A, Wunsch C (2003) Large scale ocean heat and freshwater transport during the World Ocean Circulation Experiment. J Clim 16:696-705

Ganopolski A, Rahmstorf S (2001) Rapid changes of glacial climate simulated in a coupled climate model. Nature 409:153-158

Gómez-Gesteira M, deCastro M, Alvarez I, Gómez-Gesteira JL (2008) Coastal sea surface temperature warming trend along the continental part of the Atlantic Arc (1985-2005). J Geophys Res 113:C04010 doi:10.1029/ 2007JC004315

Gómez-Navarro JJ, Montávez JP, Jerez S, Jiménez-Guerrero $\mathrm{P}$, Lorente-Plazas $\mathrm{R}$, González Rouco JF, Zorita E (2011) A regional climate simulation over the Iberian Peninsula for the last millennium. Clim Past 7:451-472

Gray ST, Graumlich LJ, Betancourt JL, Pederson GT (2004) A tree-ring based reconstruction of the Atlantic Multidecadal Oscillation since 1567 A.D. Geophys Res Lett 31:L12205 doi:12210.11029/12004GL019932

Grossmann I, Klotzbach PJ (2009) A review of North Atlantic modes of natural variability and their driving mechanisms. J Geophys Res 114:D24107 doi:10.1029/2009JD 012728

Hall IR, Boessenkool KP, Barker S, McCave IN, Elderfield H (2010) Surface and deep ocean coupling in the subpolar North Atlantic during the last 230 years. Paleoceanography 25:PA2101 doi:10.1029/2009pa001886

Huang S (2004) Merging information from different resources for new insights into climate change in the past and future. Geophys Res Lett 31:L13205 doi:13210. 11029/12004GL019781

> Hurrell JW (1995) Decadal trends in the North Atlantic Oscillation: regional temperatures and precipitation. Science 269:676-679

Keigwin LD (1996) The Little Ice Age and Medieval Warm Period in the Sargasso Sea. Science 274:1504-1507

Keigwin LD, Pickart RS (1999) Slope water current over the Laurentian Fan on interannual to millenial time scales. Science 286:520-523

Kerr RA (2000) A North Atlantic climate pacemaker for the centuries. Science 288:1984-1986

Kilbourne KH, Quinn TM, Webb R, Guilderson T, Nyberg J, Winter A (2008) Paleoclimate proxy perspective on Caribbean climate since the year 1751: evidence of cooler temperatures and multidecadal variability. Paleoceanography 23:PA20 doi:10.1029/2008PA001598

Kirov B, Georgieva K (2002) Long-term variations and interrelations of ENSO, NAO and solar activity. Phys Chem Earth 27:441-448

Knight JR, Allan RJ, Folland CK, Vellinga M, Mann ME (2005) A signature of persistent natural thermohaline circulation cycles in observed climate. Geophys Res Lett 32:L20708 doi:10.1029/2005GL024233

Lantzsch H, Hanebuth TJJ, Bender VB (2009) Holocene evolution of mud depocentres on a high-energy, lowaccumulation shelf (NW Iberia). Quat Res 72:325-336

Lebreiro SM, Frances G, Abrantes F, Diz P and others (2006) Climate change and coastal hydrographic response along the Atlantic Iberian margin (Tagus Prodelta and Muros Ría) during the last two millennia. Holocene 16:1003-1015

Lund DC, Lynch-Stieglitz J, Curry WB (2006) Gulf Stream density structure and transport during the past millennium. Nature 444:601-604

Luterbacher J, Xoplaki E, Dietrich D, Jones PD and others (2002) Extending North Atlantic oscillation reconstructions back to 1500. Atmos Sci Lett 2:114-124

> Luterbacher J, Dietrich D, Xoplaki E, Grosjean M, Wanner $\mathrm{H}$ (2004) European seasonal and annual temperature variability, trends, and extremes since 1500. Science 303: 1499-1503

Mann ME, Emanuel KA (2006) Atlantic hurricane trends linked to climate change. Eos Trans AGU 87:233-244

Margalef R (1978) Life-forms of phytoplankton as survival alternatives in an unstable environment. Oceanol Acta 1: 493-509

Mayewski PA, Rohling EE, Curt Stager J, Karlen W and others (2004) Holocene climate variability. Quat Res 62: 243-255

McCartney MS, Talley LD (1982) The Sub-Polar Mode Water of the North-Atlantic Ocean. J Phys Oceanogr 12:1169-1188

McCorkle DC, Emerson SR (1988) The relationship between pore water carbon isotopic composition and bottom water oxygen concentration. Geochim Cosmochim Acta 52:1169-1178

McGregor HV, Dima M, Fischer HW, Mulitza S (2007) Rapid 20th-century increase in coastal upwelling off northwest Africa. Science 315:637-639

Miettinen A, Koc N, Hall IR, Godtliebsen F, Divine D (2010) North Atlantic sea surface temperatures and their relation to the North Atlantic Oscillation during the last 230 years. Clim Dyn 36:533-543

Minobe S, Manabe T, Shouji A (2002) Maximal wavelet filter and its application to bidecadal oscillation over the Northern Hemisphere through the twentieth century. J Clim 15:1064-1075

Moberg A, Sonechkin DM, Holmgren K, Datsenko NM, Karlén WH (2005) Highly variable Northern Hemisphere temperatures reconstructed from low- and highresolution data. Nature 433:613-617

Moita T (2001) Estrutura, variabilidade e dinamica do fitoplancton na Costa de Portugal continental. University of Lisbon, Lisbon

Müller PJ, Kirst G, Ruhland G, Von Storch I, Rosell-Mele HA (1998) Calibration of the alkenone paleotemperature index $\mathrm{U}_{37}{ }^{\mathrm{K}^{\prime}}$ based on core-tops from the eastern South Atlantic and the global ocean $\left(60^{\circ} \mathrm{N}-60^{\circ} \mathrm{S}\right)$. Geochim Cosmochim Acta 62:1757-1772

Narayan N, Paul A, Mulitza S, Schulz M (2010) Trends in coastal upwelling intensity during the late 20th century. Ocean Sci 6:815-823 doi:10.5194/os-6-815-2010

Nuñez-Riboni I, Haak H, Bersch M, Jungclaus J (2010) Interannual and decadal variability of the Subpolar Gyre and the Meridional Overturning Circulation in the North Atlantic. Geophys Res Abstr 12:EGU2010-EGU7191 
Oliveira PB, Moita T, Catarino R, Silva AJ (2007) Wintertime SST and chl $a$ off NW Iberian shelf from satellite and in-situ data. Joint 2007 EUMETSAT Meteorological Satellite Conference, and the 15th Satellite Meteorology \& Oceanography Conference of the American Meteorological Society, Amsterdam, 24-28 September 2007, available at www.eumetsat.int/Home/Main/Publications/ Conference_and_Workshop_Proceedings/groups/cps/ documents/document/pdf_conf_p50_s5_05_oliveira_p.pdf

Ortiz JD, Rack FR (1999) Non-invasive sediment monitoring methods. Current and future tools for high-resolution climate studies. In: Abrantes F, Mix A (eds) Reconstructing ocean history: a window into the future. Kluwer Academic/Plenum Publishers, New York, NY, p 343-380

Peinert R, Bodungen BV, Smetacek VS (1989) Food web structure and loss rate. In: Berger WH, Smetacek VS and Wefer G (eds) Productivity of the ocean: present and past. Wiley, Chichester, p 35-48

Peterson LC, Haug GH, Hughen KA, Roehl U (2000) Rapid changes in the hydrologic cycle of the Tropical Atlantic during the Last Glacial. Science 290:1947-1951

Reimer P, Baillie M, Bard E, Bayliss A and others (2004) INTCAL04 terrestrial radiocarbon age calibration, 0-26 cal kyr BP. Radiocarbon 46:1029-1058

Relvas P, Barton ED, Dubert J, Oliveira PB, Peliz Á, Silva JCB, Santos AMP (2007) Physical oceanography of the western Iberia ecosystem: latest views and challenges. Prog Oceanogr 74:149-173

Rios AF, Pérez FF, Fraga F (1992) Water masses in the upper and middle North Atlantic Ocean east of the Azores. Deep-Sea Res A 39:645-658

Rogers C (1985) Atmospheric circulation changes associated with the warming over the northern North Atlantic in the 1920s. J Clim Appl Meteorol 24:1303-1310

Salgueiro E, Voelker A, Abrantes F, Meggers H and others (2008) Planktonic foraminifera from modern sediments reflect upwelling patterns off Iberia: insights from a regional transfer function. Mar Micropaleontol 66:135-164

Schlesinger ME, Ramankutty N (1994) An oscillation in the global climate system of period $65-70$ years. Nature 367 : 723-726

Schulz M, Mudelsee M (2002) REDFIT: estimating red-noise spectra directly from unevenly spaced paleoclimatic time series. Comput Geosci 28:421-426

Sicre MA, Jacob J, Ezat U, Rousse S and others (2008) Decadal variability of sea surface temperatures off North Iceland over the last 2000 yrs. Earth Planet Sci Lett 268: 137-142

Sousa P, Trigo RM, Aizpurua P, Nieto R, Gimeno L, GarcíaHerrera R (2011) Trends and extremes of drought indices throughout the 20th century in the Mediterranean. Nat Hazards Earth Syst Sci 11:33-51

Stein R (1991) Accumulation of organic carbon in marine sediments. Lect Notes Earth Sci 34 XIII. Springer, Berlin

- Stuiver M, Braziunas T (1989) Atmospheric ${ }^{14} \mathrm{C}$ and centuryscale solar oscillations. Nature 338:405-408

> Thierry V, de Boisséson E, Mercier H (2008) Interannual variability of the Subpolar Mode Water properties over the Reykjanes Ridge during 1990-2006. J Geophys Res 113:C04016 doi:10.1029/2007jc004443

Thornalley DJR, Elderfield H, McCave IN (2009) Holocene oscillations in temperature and salinity of the surface subpolar North Atlantic. Nature 457:711-714

> Trauth MH, Sarnthein M, Arnold M (1997) Bioturbational mixing depth and carbon flux at the seafloor. Paleoceanography 12:517-526

Trigo RM, Osborn TJ, Corte-Real J (2002) The North Atlantic Oscillation influence on Europe: climate impacts and associated physical mechanisms. Clim Res 20:9-17

> Trigo RM, Pozo-Vazquez D, Osborn TJ, Castro-Diez Y, Gamis-Fortis S, Esteban-Parra M (2004) North Atlantic oscillation influence on precipitation, river flow and water resources in the Iberian Peninsula. Int J Climatol 24:925-944

Trouet V, Esper J, Graham NE, Baker A, Scourse JD, Frank DC (2009) Persistent positive North Atlantic Oscillation mode dominated the medieval climate anomaly. Science 324:78-80

Villanueva J, Grimalt JO (1997) Gas chromatographic tuning of the $\mathrm{U}^{\mathrm{K}^{\prime}}{ }_{37}$ paleothermometer. Anal Chem 69:3329-3332

Villanueva J, Pelejero C, Grimalt JO (1997) Clean-up procedures for the unbiased estimation of C37 alkenone sea surface temperatures and terrigenous n-alkane in paleoceanography. J Chromatogr A 757:145-151

> Vinther BM, Andersen KK, Hansen AW, Schmith T, Jones PD (2003) Improving the Gibraltar/Reykjavik NAO index. Geophys Res Lett 30:2222 doi:10.1029/2003GL 018220

Vitorino J, Oliveira A, Jouanneau JM, Drago T (2002) Winter dynamics on the northern Portuguese shelf. 2. Bottom boundary layers and sediment dispersal. Prog Oceanogr 52:155-170

> Wanamaker ADJ, Kreutz KJ, Schöne BR, Pettigrew N and others (2008) Coupled North Atlantic slope water forcing on Gulf of Maine temperatures over the past millennium. Clim Dyn 31:183-194

Wilson R, D'Arrigo R, Buckley B, Büntgen U and others (2007) A matter of divergence: tracking recent warming at hemispheric scales using tree ring data. J Geophys Res 112:D17103 doi:17110.11029/12006JD008318

Proofs received from author(s): August 11, 2011 